ORNL -4748

UC-41 - Health suld Saret?

UC-35 - ituclear Expiosions - PEaceful Applications

\title{
THEORETICAL ZVALUATION OF CONQUAES
}

PROQUCTS FRCA FROJECT GASBUGIY

riYAL REPORT

PHASE II: HYPOTHETCKL POPULATIJE

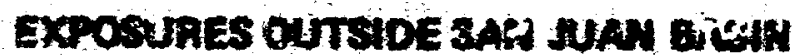
D. G. Jocols
C. A. Bowmin
C. Al Berton
Th. Honis
M. J. Kelly F.A. Gthrd, Jt.
W. Nulkowisi

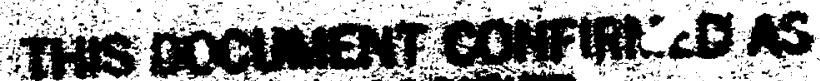

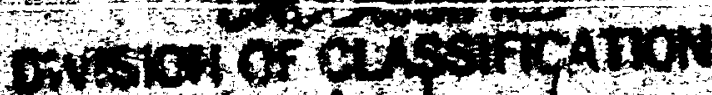

* onlmolnos

$6 \sqrt{1} 36,2$

\section{OAK RIDGE A RTIONAL LABORATORY opwated by \\ UNION CAKB, SORPORATION \\ for the}

U. 5. ATOMic ENEREY COMMISSION 


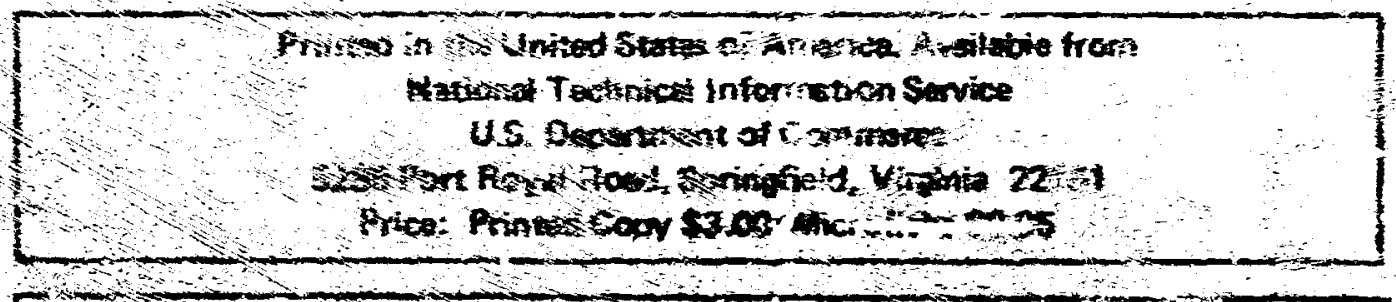

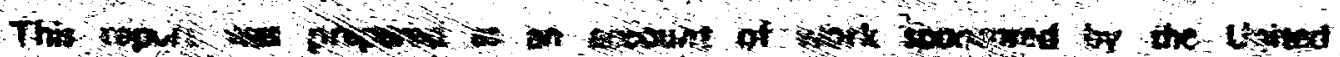

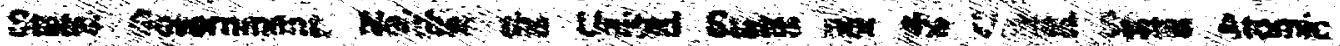

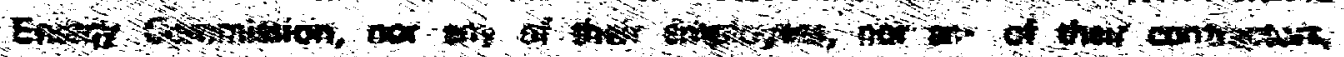

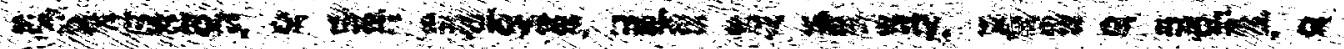

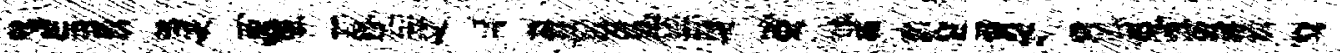

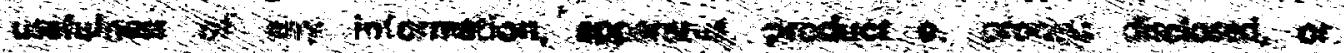

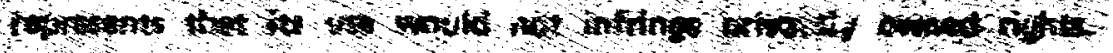




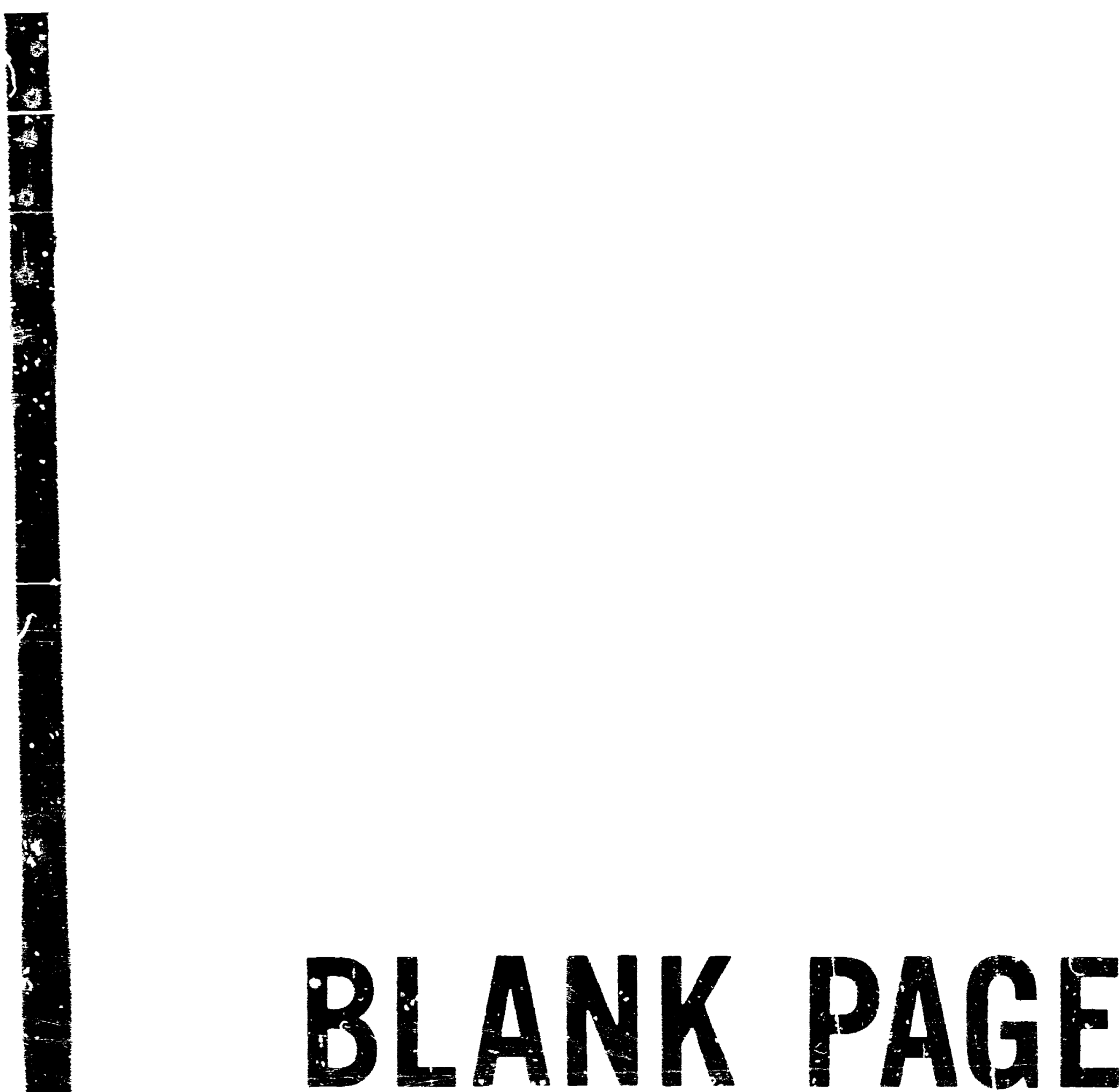


Contract No. W-7405-ens-26

HEALTH PHYSICS DIVISION

THEORETICAL EVALUATION OF CONSHMER

PRODUCTS FROM PROJECT GASBUGGY

FINAL REPORT

PHASE II: HYPOTHETICAL POPULATION

EXPOSURES OUTSIDE SAN JUAN BASIN

D. G. Jacobs

C. R. Bowman

C. J Barton

S. R. Hanna

M. J. Kelly

F. A. Gifford, Jr.

W. M. Culkowski

NOTICE

This report wh prepered as account of work somecred by the United Stries Govemment. Netther the United States nor the United States Atomic Enenty Comminuion, nor any of thet employes, nor any of their coutractors, eubcontractors, or thet smployees,

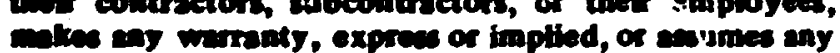

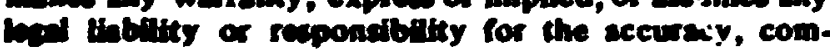

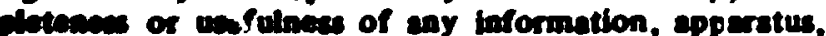
modeet or proesen diveloned, or represents that hts we would not infiflape porfvety owned rights.

OAK RIDGE NATIONAL LABORATORY

Oak Ridos, Tennease 37830

operoted by

UNION CARBIDE CORPORATION

for the

U.S. ATOMIC ENERGY COMMISSICN 


\section{Canionis}

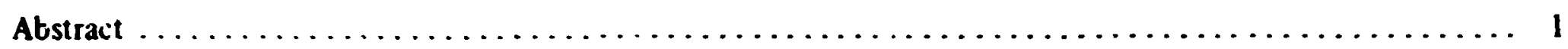

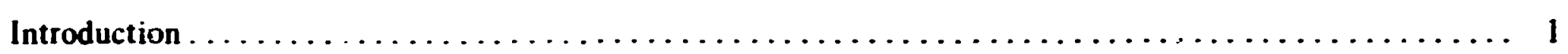

Possible Exposures to Petrochemicals and Other Nonfuel Products from Contaminated

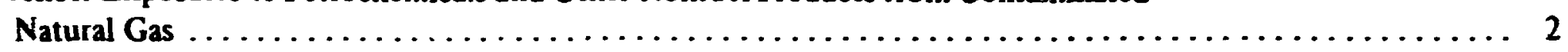

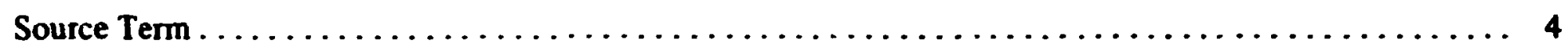

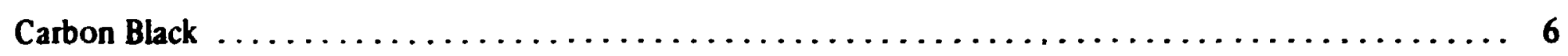

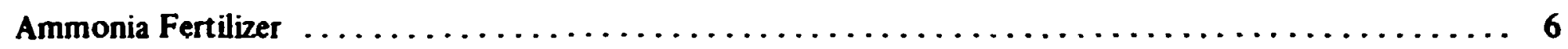

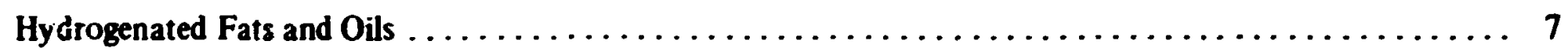

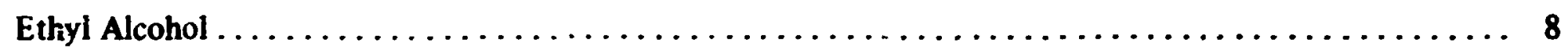

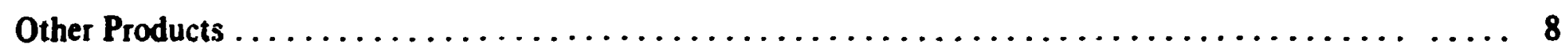

Disposition of Liquids Hypothetically Recovered from Gasbuggy Gas $\ldots \ldots \ldots \ldots \ldots \ldots \ldots \ldots \ldots .8$

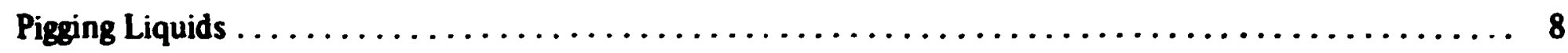

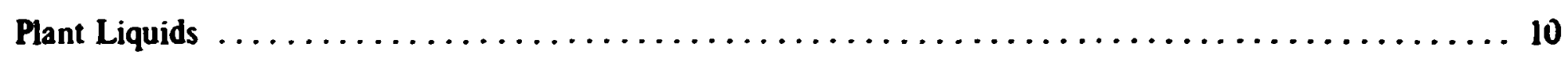

Hypothetical Population Exposure in the Metropolitan Areas $\ldots \ldots \ldots \ldots \ldots \ldots \ldots \ldots \ldots \ldots$

Hypothetical Use of Nuclearly Stimulated Gas in a Large Electric Plant in Los Angeles $\ldots \ldots \ldots \ldots \ldots \ldots 18$

Appendix A. The ATDL Area.Source Model $\ldots \ldots \ldots \ldots \ldots \ldots \ldots \ldots \ldots \ldots \ldots \ldots \ldots \ldots \ldots \ldots \ldots \ldots \ldots$

Appendix B. Atmospheric Dispersion of Gas Combustion Products from a 1000-MW(e) Electric

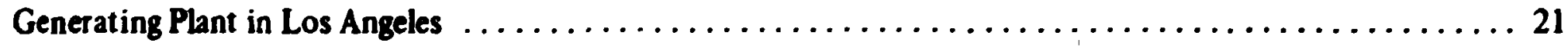




\title{
THEORETICAL EVALUATION OF CONSUHER PRODUCTS FROM PROJECT GASBUGGY, FINAL REPORT. PHASE II. HYPUTHETICAL POPULATION EXPOSURES OUTSIDE THE SAN JUAN BASIN
}

\author{
D. G. Jacobs \\ C. R. Bowman' \\ C. J. Barton \\ S. R. Hanna ${ }^{2}$ \\ M. J. Kelly \\ F. A. Gifford, Jr. ${ }^{2}$
}

W. M. Culkowski

\begin{abstract}

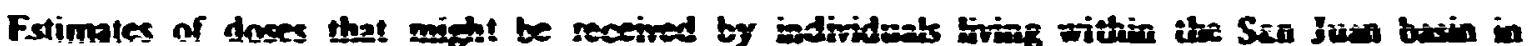
westem New Mexico from the hypothetical use of Gasbuss go were given in a previous report (ORNL-4646). This report extends those studies to include potential doses to individuals in west covest metropolitin areas. Tritium is the rodionclide of most concern. Calculations show that a maximnm annul radiation dose of 2.2 to 2.5 mitirema/year might be attined in these areas if gas contrining 1 $\mathrm{pCI} / \mathrm{cm}^{3}$ of tritium were used in homes hrving unvented spoce heaters. The potential average anoul dose to members of the peblic in the saue areas is estimated to be about 0.5 milirem/year. These doses, as well as potential doses resulting from une of liquid bydrocaboas separated from gas and from possible use of by-products monufactured with tritium-contaminated as frections, were small compared with the Federal Radiation Councirs Radiation Rrotection Guide of 170 millirema/year (whok body) and with beckground radintion levelb is the normal homon envinonment.
\end{abstract}

\section{INTRODUCTION}

A theoretical evaluation of doses that would be anticipated irom the hypothetical utilization of natural gas from the Gasbuszy cavity was initiated at ORNL during the latter part of 1968 . This study is divided into three parts. ${ }^{3}$ Phase I was concerned with the impact of the hypothetical injection of Casbusy gas into the gas collection network of the San Juan Division of El Paso Natural Gas Compariy (EPNG). Results of this study, reported initially in project progress reports, ${ }^{4-7}$ have been collected in a :opical report $t^{2}$ and described in the open literature. 9,10 Phase 11 considers hypothetical exposures from use of Gabuesy gas or from natural bys by-products by consumers outside the San Juan basin. Phaxe III, covering the radiological safety asessment of the development of an entire naturd gas reservoir by use of nucles explosives, is being dehayed pending the availability of data on probable radioisotope content of natural gas from wells stimulated by nuciear explosives especially designed for the purpor. This work is not presently considered 'o be part of the Gasbugzy project. The Minista event, conducted at the Nevada test site on July 8, 1971,

1. El Paso Natural Gas Company, El Paso, Tex.

2. Air Resources Atmospheric Turbulence and Diffusion Laboratory, National Oceanic and Aimospheric Administration, Oak Ridge, Tem.

3. D. G. Jacobs, E. G. Struxness, and M. J. Kelly, First Quarterly Progress Report on the Theoretical Safety Evaluation of Consumer Products from Project Casbressy. ORNL-TM-2427 (February 1969).

4. M. J. Kelly et al, Second Quarterly Progess Report on the Theoretical Emhuation of Consumer Products from Project Gasburesy, ORNL-TM-25 13 (March 1969).

5. D. G. Jacobs, P. S. Rohwer, and K. E. Comer, Thind Querterty Frospess Report on the Therentical Evaluation of Consermer Products from Project Gasbuesy, ORNL-TM-2657 (July 1969).

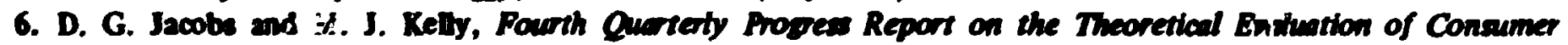
Froducts from Project Casbuss, BRNL-TM-2721 (October 1969).

7. D. G. Jacobs and M. J. Kelly, Fifth Queterly Progess Report on the Theoretical Evaluntion of Consurner Products from Project Gesuredy, ORNL-TM-2862 (Febn'ary 1970).

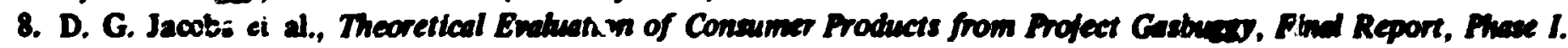
Impact of Hypothetical Releases of Contamtinsted Ges in the San Juen Bastn, ORNL 1646 (September 1971).

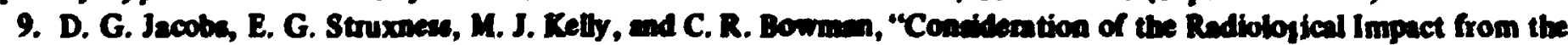
Hypothetical Use of Contaminated Gas from Nucleaty Stimalnted Reservoirs," Health Fhys. (in prem).

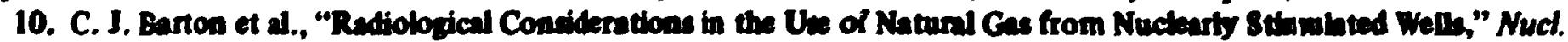
Tecinol 11, 335 (1971). 
BLANK PAGE 
was the first test of an explosive designed specifically for underground use. Its success seems to ensure lower tritium concentrations in future gas stimulation tests than were observed in the Rulison and Gasbuggy experimerts, but data on actual tritium production of commercialiy useful explosives are not now availabie.

A large fraction of the gas produced in the San Juan Divisic - of El Paso Natural Gas Company is consumed in uest cuast metropolitan areas, principally Los Angeles and San Francisco, and this report considers the hypothetical inipact of Gasbuggy gras in these areas. Appendix A describes the computational techniques used to calculate ground tevel concentrations of radioisotopes from both ground level and elevated point-source releases, and Appendix B contains the calisulations of the tritium concentration in combustion products from a large gas-fired electric generating piant located in Los Angeles. Although ti: quantities of natural gas components from this area that are converted into gas by-products are not readily available, we have assumed that such products would be manufactured from tritium-containing gas and have calculated doses that could result from exposure to the most important products or manufacturing processes. The ${ }^{85} \mathrm{Kr}$ in the natural from nuclear!y stimulated wells is believed to be of minor importance in respect to possible doses from gas or gas by-products.

\section{POSSIBLE EXPOSURES TO PETROCHEMICALS AND OTHER NONFUEL PRODUCTS FROM CONTAMINATED NATURAL GAS}

A preliminary repori was published earlier" ' containing doses that might be received from exposure to consumer products made with natural gas containing radioisotopes. A large and rapidly growing quantity of natural gas components is converted to a variety of chemical products usually called petrischemicals, and we will consider in this section the possible impact of redioisotope impurivies on consumers.

Data ${ }^{12}$ on amounts of the major petrochemicals produced in the period 1965-68 are shown in Table 1. Some of the products listed are marketed without further treatment, but others serve as intermediates in the manufacture of materials such as synthetic rubber, detergents, fibers, resins, plastics, plasticizers, and fertilizers. Many of the materiais come from oil rather than natural gas. Figure 1 shows the disposition of natural hydrocarbons in $1956 .{ }^{13}$ Spot checks of this disposition from more recent production data ${ }^{12}$ indicated that it has not changed drastically in the last 15 years, although there is a definite trend toward increased recovery of ethane and higher natural gas hydrocarbons for nonfuel usage.

11. C. J. Barton, D. G. Jacobs, and M. J. Kelly, Quartely Progess Report on Radiolozical Sefety of Peareful Uses of Nucleor Explosives: Consumer Products from Nuclewoly Stimulated Gas Wells, ORNL-TM-31 23 (Septemrer 1970).

12. F. G. Sawyer, "Petrochemicals: Near Great in '59," Hydrocarbon Proc. 47(4), 187 (April 1968).

13. V. B. Guthrie, ed., Petroleum Products Handbook, pp. 12-15, KCGraw-Hill, New York, 1960.

14. C. F. Smith, Jr., Gas Analysis Results for Project Rulison Calibration Flaring Samples, UCRL-50986 (January 1971).

Table 1. Majoc petrochemicals - capacity and prodectione

\begin{tabular}{|c|c|c|c|c|c|c|c|}
\hline & \multirow{2}{*}{\multicolumn{2}{|c|}{$\begin{array}{l}\text { Capacity } \\
\text { estimated }\end{array}$}} & \multicolumn{5}{|c|}{ Production } \\
\hline & & & \multicolumn{2}{|c|}{ Actual } & \multicolumn{2}{|c|}{ Estimated } & \multirow{2}{*}{$\begin{array}{c}\text { Percest } \\
\text { petrochemica }\end{array}$} \\
\hline & 1967 & 1968 & 1965 & 1966 & 1967 & 1968 & \\
\hline \multicolumn{8}{|l|}{ Hydrocarbon intermediates } \\
\hline \multicolumn{8}{|l|}{ Aliphatic } \\
\hline Ethylene & 14,000 & 15,000 & 9,570 & 11,240 & 12,200 & 13,000 & 100 \\
\hline Propylene and mixtures & 6,000 & 6,500 & 3,740 & 4,680 & $5, \mathbf{3 0 0}$ & 6,000 & 100 \\
\hline Butylene and mixtures & 3,300 & 4,000 & 2,100 & 3,320 & 3,650 & 4,000 & 100 \\
\hline Butadiene & 3,050 & 3,110 & 2,690 & 2,920 & 2,670 & 3,000 & 100 \\
\hline Acetylene & 1,550 & 1,760 & 1,150 & 1,400 & 1,550 & 1,700 & so \\
\hline
\end{tabular}


Tabte I (continued)

\begin{tabular}{|c|c|c|c|c|c|c|c|}
\hline & \multirow{2}{*}{\multicolumn{2}{|c|}{$\begin{array}{l}\text { Capacity } \\
\text { estimated }\end{array}$}} & \multicolumn{5}{|c|}{ Production } \\
\hline & & & \multicolumn{2}{|c|}{ Actual } & \multicolumn{2}{|c|}{ Estimated } & \multirow{2}{*}{$\begin{array}{l}\text { Percent } \\
\text { petrochemical }\end{array}$} \\
\hline & 1967 & 1968 & 1965 & 1966 & 1967 & 1968 & \\
\hline \multicolumn{8}{|l|}{ Aromatic } \\
\hline Benzene & 8,000 & 9,200 & 6,060 & 6,980 & 7,030 & 7,500 & 90 \\
\hline Cyciohexane & 2,700 & 2,800 & 1.700 & 1,900 & 1,670 & 1,800 & 100 \\
\hline Cyclopropine & 200 & 200 & 130 & 120 & 110 & 100 & 90 \\
\hline Cumer.e & 1,420 & 1.750 & 660 & 890 & 1,100 & 1.400 & 95 \\
\hline Ets; ibenzere & 4,000 & 4,200 & 3,020 & 3,250 & 3,450 & 3,700 & 90 \\
\hline Niphthalene & 900 & 900 & 810 & 800 & 880 & 900 & 42 \\
\hline Styrene & 3,210 & 4,000 & 2,760 & 3,190 & 3,280 & 3,400 & 90 \\
\hline Tohuene & 4,700 & 4,700 & 3,980 & 4,230 & 4,33i & 4,500 & 97 \\
\hline Xylene & 4,000 & 4,200 & 2,490 & 3,150 & 3,470 & 3,700 & 99 \\
\hline \multicolumn{8}{|l|}{ Polymers } \\
\hline Polyethylene & 4,500 & 4,700 & 3,050 & 3,560 & 3,710 & 4.150 & 100 \\
\hline Polypropylene & 650 & 800 & 379 & 550 & 650 & 800 & 100 \\
\hline Polyvinyl chloride and copolymers & 2,780 & 2,900 & 1,840 & 2,160 & 2,080 & 2,450 & 90 \\
\hline Styrene polymers & 2,330 & 2,500 & 2,030 & 2,380 & 2,370 & $2,75 \mathrm{C}$ & 90 \\
\hline Syntheiic rubber & 3,990 & 4,000 & 3,590 & 3,930 & 3,700 & 4,150 & 90 \\
\hline \multicolumn{8}{|l|}{ Aromatic chemicals } \\
\hline Chlorobenzene & 650 & 650 & S50 & 580 & 490 & 490 & 60 \\
\hline Nitrobenzene & 380 & 380 & 280 & 330 & 360 & 400 & 60 \\
\hline Phencl & 1,650 & 1,800 & 1,250 & 1,350 & 1,240 & 1,300 & 96 \\
\hline Phthelic anhydride & 800 & 1,000 & 610 & 680 & 720 & 730 & 60 \\
\hline \multicolumn{8}{|l|}{ Aliphatic chemicak } \\
\hline Acetaldehyde & 1,660 & 1,800 & 1,230 & 1,300 & 1,400 & 1,500 & 80 \\
\hline Acetic acid & 2,030 & 2,030 & 1,350 & 1,410 & 1,500 & 1,600 & sn \\
\hline Acetic anhydride & 1,660 & 1,800 & 1,530 & 1,600 & 1,550 & 1,600 & 39 \\
\hline Acetone & 1,400 & 1,500 & 1,120 & 1,330 & 1,210 & 1,300 & 85 \\
\hline Acrylonitrile & 1,030 & 1,030 & 770 & 720 & 670 & 700 & 100 \\
\hline Butanols & 900 & 900 & 830 & $490^{6}$ & $520^{\circ}$ & $520^{\circ}$ & 8 \\
\hline Carbon disulfide & 900 & 900 & 760 & 750 & 570 & 570 & 85 \\
\hline Carbon tetrachloride & 740 & 740 & 590 & 540 & 710 & 750 & 95 \\
\hline Ethanol & 2,800 & 2,800 & 2,530 & 2,200 & 2,130 & 2,150 & 95 \\
\hline Ethyl chloride & 800 & 750 & 690 & 600 & 690 & $6 \infty$ & 100 \\
\hline Ethylene dichloride & 2,900 & 3,206 & 2,460 & 3,620 & 3,600 & 4,000 & 100 \\
\hline Ethylene dycol & 2,430 & 2,430 & 1,800 & 2,000 & 2,150 & 2,200 & 95 \\
\hline Ethylene oxide & 3,000 & 3,400 & 2,190 & 2,330 & 2,260 & 2,400 & 99 \\
\hline Fhucrocarbons & 725 & 725 & 460 & 460 & 500 & 550 & 100 \\
\hline Formaldehyde (100\%) & 1,700 & 1,800 & 1,159 & 1,370 & 1,360 & 1,500 & 98 \\
\hline Glycerol & 430 & 430 & 350 & 350 & 360 & 370 & 58 \\
\hline Isopropand & 1,760 & 2,310 & 1,540 & 1.710 & 1,850 & 2,000 & 100 \\
\hline Maleic anhydride & 200 & 210 & 130 & 170 & 170 & 100 & 30 \\
\hline Methanol & 4,000 & 4,300 & 2,870 & 3,270 & 3,450 & 3600 & 99 \\
\hline Methyl chloride & 375 & $\$ 50$ & 190 & 240 & 260 & ax & 90 \\
\hline Methylene chloride & 335 & 350 & 210 & 270 & 200 & 250 & 100 \\
\hline Oxo chemicals & 850 & 850 & 500 & 570 & 510 & 600 & 100 \\
\hline Perchloroethylene & 535 & 600 & 430 & 460 & 530 & 600 & 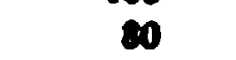 \\
\hline Propylene glycol & 310 & 330 & 210 & 260 & 280 & 300 & 100 \\
\hline Fropylene oxide & 870 & 1,020 & 600 & 710 & 800 & 930 & 100 \\
\hline Trichloroethylene & 645 & G45 & 430 & 480 & 490 & sod & so \\
\hline Urea & 5,000 & 6,000 & 2,570 & 3,430 & 4,200 & 4,500 & 99 \\
\hline Vinyl scetate & 780 & 80 & 510 & 610 & 610 & 6 & 75 \\
\hline Vinyl chloride & 3,300 & 3,500 & 2,600 & 2,500 & 2,130 & 2,600 & 90 \\
\hline Ammonia & 30,400 & 36,000 & 17,200 & 21,320 & 25,000 & 30,000 & 99 \\
\hline
\end{tabular}

All figures in millions of pounds.

$b_{n-B u t y l}$ and ienbutyl only. 


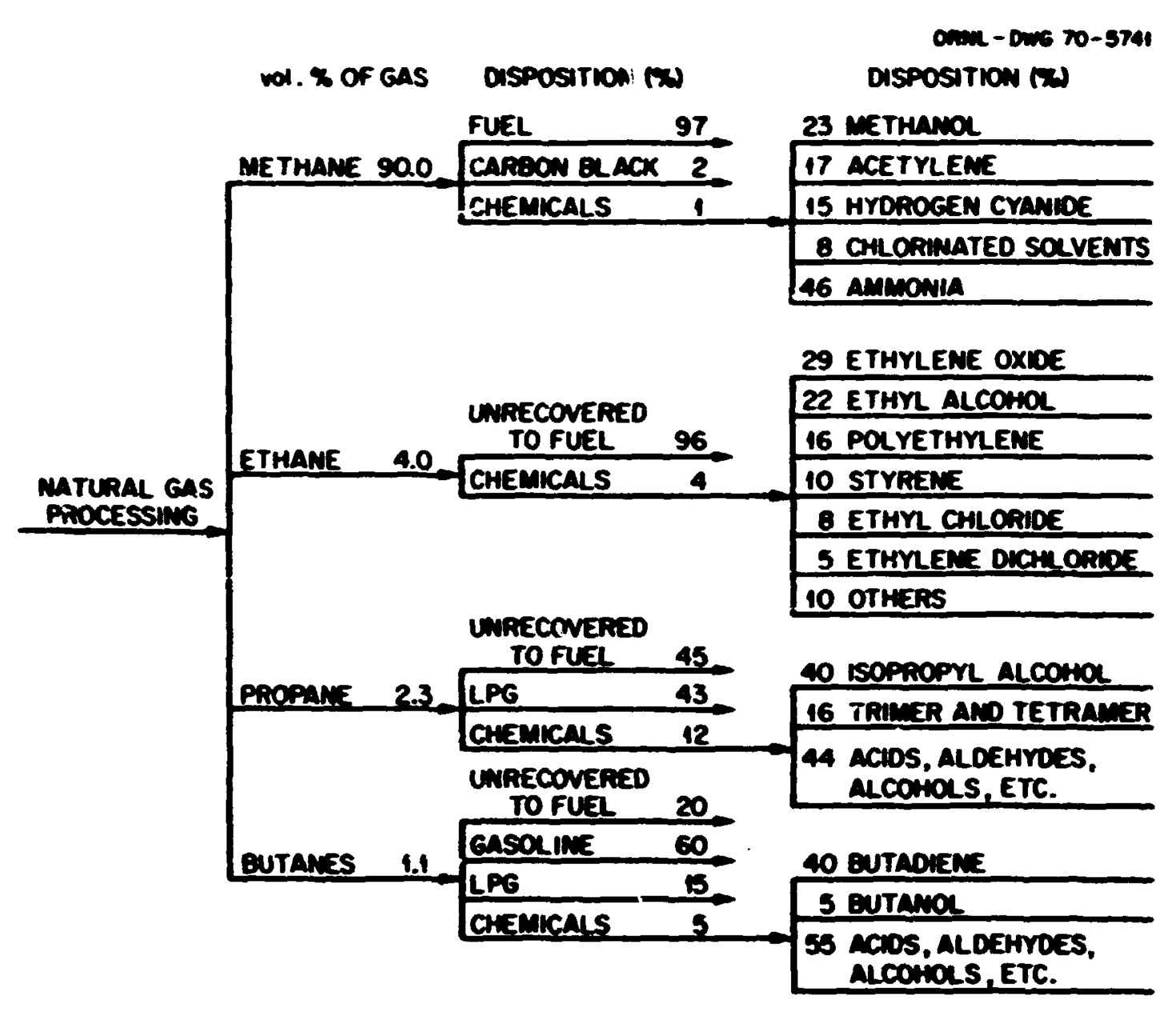

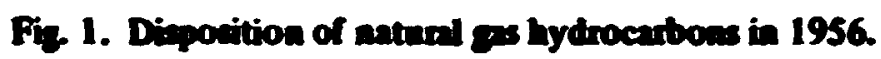

\section{Source Term}

In our calculations of potential exposures to nonfuel products, we have essentially ignored the Casbugey andytical data ${ }^{15}$ and adopted the value $1 \mathrm{pCi} / \mathrm{cm}^{3}$ for the total tritium concentration in the gas at the processing plant, that is, just before the tritium-containing components used to make petrochemicals are separated from the raw gas. There are several reasons for this decision. One is that the tritium content of Gasbugsy gas is almost certainly much higher than will be observed in future nuclearly stimulated wells, as indicated by analytical data on gas from the Rulison well ${ }^{14}$ and by the published statement ${ }^{16}$ that non-weapon-type nuclear explosives will produce less tritium than was found in the Gasbugeg and Rulison tests. It should be noted that production testing of the Gasbuggy ${ }^{15}$ and Rulison ${ }^{17}$ wells ceased after approximately two cavity volumes of gas had been removed. Many cavity volumes of gas would be produced during the lifetime of a commercial well, generally assumed to be at least 20 years. For the Rulison case, the average tritium concentration during the production life of the well was calculated to be 6 to $8 \mathrm{pCi} / \mathrm{cm}^{3}$. We believe it is reasonable to assume that the average tritium concentration will be 1 $\mathrm{pCi} / \mathrm{cm}^{3}$ ni less for large-scale development of a reservoir through nuclear stimulation with improved nuclear explosives, where newly stimulated wells will be brought into production as the quantity of gas from other wells declines. Another, less important, consideration is that analytical data are generally

15. C. F. Smith, Jr., Project Gasbussy Gas Quality Analyds and Evatuation Program Tabulation of Radiochemical and Chemital Analytical Results, UCRL-50635, rev. 1 (November 1969).

16. G. C. Werth et al., An Analysis of Nuclear Explostre Gas Stimulation and the Program Required for Its Development, UCRL-50966 (April 1971).

17. R. L. Gotchy, Project Rulison Interim Radioactivity Reports (January, February, May 1971). 
reported in picocuries per cubic centimeter and that doses calculated on the basis of the value of $1 \mathrm{pCi} / \mathrm{cm}^{3}$ can be adjusted easily by use of appropriate concentration values.

In spite of the above assumption, it is interesting to examine data on changes of concentration with the volume of gas removed from the cavity.

By combining data reported by Smith ${ }^{15}$ on the chenical composition with the radioisotope content of Gasbuggy samples, specific activities $\left(\mathrm{pCi} / \mathrm{cm}^{3}\right)$ of gas components can be calculated. The data are rather scanty for propane (11 samples) but are sufficient to show the effect of gas withdawal. The results of these calculations are plotted in Fiz. 2 (see ref. 8, p. 30, for a discusion of $V_{0}$ ). The effect of the diffuicion of formation gas into the cavity, as gas was withdrawn, on the specific activity of the hydrocarbons is quite evident. It is most marked in the case of propane because there was a barger difference between the propane content of the formation gas and the concentration in the cavity gas, as compared with methine and ethane.

The significance of the data in Fig. 2 in regard to calculation of potential doses from groducts is that the tritium content of the various gas components may not change at the same rate when gos is removed from a nuclearly stimulated well. Sufficient data on the specific activity of butane and higher hydrocarbons are not avaibble at present to define trends for these ges components.

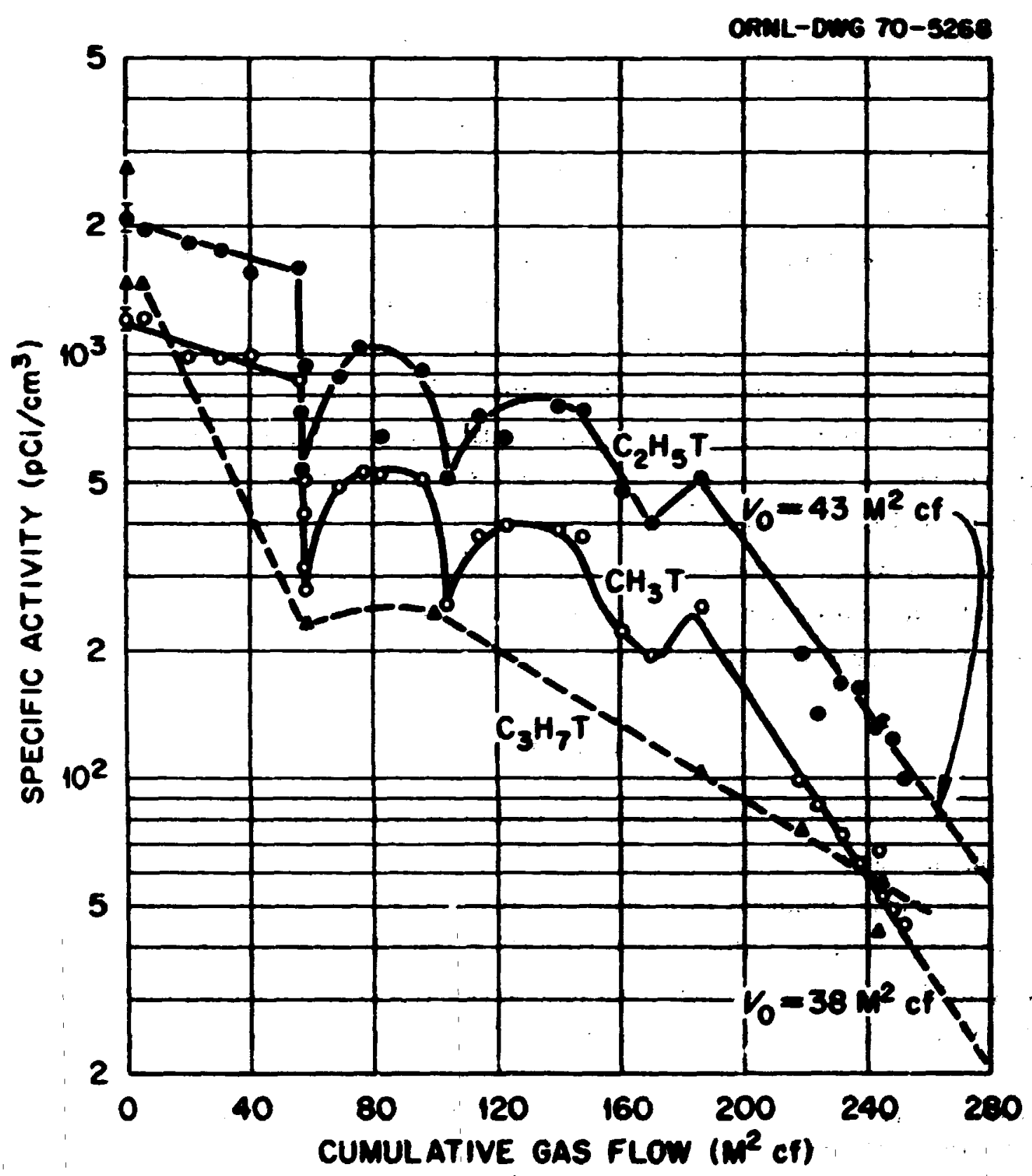

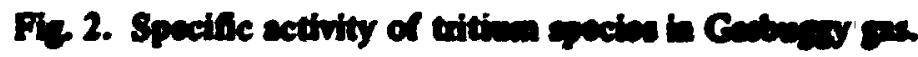


An average cuncentration of $1 \mathrm{pCi} / \mathrm{cm}^{3}$ for total tritium seems reasonable, as was discussed earlier in this section. The comparable figure for " ${ }^{5} \mathrm{Kr}$ nay be somewhat higher, but this is not important because of the retalively smenl biokgical impact of this isatope.

\section{Cariben Alack}

In 1966. the lotel production of carbon black from natural gas and liquid hydrocarbons was $2.57 \times 10^{9}$ Ib. ${ }^{18}$ It is obvious that the only radinisolupe that will be fo: $\mathrm{d}$ in carbon black is ${ }^{14} \mathrm{C}$. From the reported ${ }^{14} \mathrm{C}$ concentration of $0.5 \mathrm{pCi} / \mathrm{cm}^{3}$ in Gasbuggy gas, ${ }^{15}$ we $c$ :ulate a value of approximately $10^{3} \mathrm{pCi} / \mathrm{g}$ in urbon black produced from undiluted Gasbuezy gas. Statistics's on sales of carbon black for 1964 and 1965 show that about $0.4100 .5 \%$ of this product was used as a chemical or in food production. It seems unlikely that the concentration of carbon black in food products would exceed a few tenths of a percent, but at $1 \%$ the ${ }^{14} \mathrm{C}$ content of the food material would be $10 \mathrm{pCi} / \mathrm{s}$.

If we asoume a daily intake of $500 \mathrm{~g}$ of carbon-containing food, the ${ }^{14} \mathrm{C}$ ingested would amount to $5 \times 10^{-3} \mu \mathrm{Ci} / \mathrm{dxy}$. Considering bone as the critical organ and uxing the bone dose factor $1 \mu \mathrm{Ci}$ of ${ }^{14} \mathrm{C}=2.6$ millirems, this intake rate corresponds to a daily dose of 0.013 millirem or 4.8 millirems per year. This is a conservative upper limit for possible exposure through this pathway.

We must also consider the potential radiological impact from exposure to radioisotopes in the combustion products evolved in manufacturing carbon black. It is likely that a number of years will be required to develop widespread exploitation of nuclear stimulation of natural gas reservoirs. Therefore, a projection of future gas use is needed to evaluate the impact of certain aspects of contaminated gas usage including carbon black. The 1969 edition of Gas Facts' ${ }^{19}$ has such a projection to 1990 . We selected the 1980 total sales figure of 27 ! billion therms, equivalent to 25.2 trillion cubic feet of gas, for these alculations. Assuming that the distribution shown in Fig. 1 applies to 1980 gas production, the yearly consumption of natural gas for carbon-black production (assuming that only gas is used) could be $4.5 X$ $10^{11} \mathrm{ft}^{3}$. which would contain $1.3 \times 10^{4} \mathrm{Ci}$ of tritium or ${ }^{85} \mathrm{Kr}$. This is equivalent to $35 \mathrm{Ci} /$ day of tritium $\sigma^{85} \mathrm{Kr}$. If we further ascume no change in the number of United States carbon-black plants in the interval 1966-80 and that all 34 phants existing in 1966 are equal in size, each phant would emit 1 Ci/day of tritium and of ${ }^{85} \mathrm{Kr}$. The annuad tritium production rate of $1.3 \times 10^{4} \mathrm{Ci}$ from carbon-black production is much lower than the natural production rate of 4 to $8 \times 10^{6} \mathrm{Ci} /$ year. These phnt emission rates are quite low, and the radioisotopes woulc be diluted and dispersed in the atmosphere through plant stacks. (Difficulties that these plants are experiencing in meeting environmental quality requirements could reduce their number to zero before the advent of large-scale gas stimulation.)

\section{Ammonia Fertilizer}

Ammonia is produced by the reaction of hydrogen from natural gas with nitrogen. Hydrogen production from all sources was recently reported ${ }^{20}$ to be $2.5 \times 10^{12} \mathrm{ft}^{3}$. The same publication showed that hydrogen was being produced from methane at a cost of $\$ 0.21 / \mathrm{M} \mathrm{ft}^{3}$ compared with $\$ 4 / \mathrm{M} \mathrm{ft}^{3}$ by electrolysis. (In the natural gas industry $M=10^{3}, M^{2}=10^{6}$.) It seems safe to assume, therefore, that all synthetic $\mathrm{NH}_{3}$ used in fertilizers comes from natural gas. It was also reported that $35 \%$ of the $h$, drogen $\left(8.75 \times 10^{11} \mathrm{ft}^{3} /\right.$ year) was used to make ammonia. ${ }^{20}$ Since two volumes of hydrogen are produced from

18. U.S. Buneaw of Miver, Minerals Yewbook - 1967, vots. I and 11, pp. 263-72, Wachington, D.C., 1968.

19. Americum Ges Amociation, Iac., 1969 Cas Focts, New Yort, 1969. 1969 .

20. J. H. Finneran and J. P. Mazur, "Punt Size and Feed, Key to Lower Hydrogen Costs," Oll Gas J. 67(29) (July 21, 
each volume of methane, assuming $100 \%$ conversion, $4.4 \times 10^{11} \mathrm{ft}^{3} / \mathrm{year}$ of $\mathrm{CH}_{4}$ would be required to produce this amount of hydrogen. This is equivalent to $5.8 \times 10^{11} \mathrm{ft}^{3}$ of $\mathrm{NH}_{3}$ or $2.8 \times 10^{10} \mathrm{Bb} \mathrm{NH}$ per year.

If we assume that the tritium concentration in astural gas is $1 \mathrm{pc} / \mathrm{cm}^{3}$ and that all the tritium is present as $\mathrm{CH}_{3} \mathrm{~T}$, the resulting tritium concentration in $\mathrm{NH}_{3}$ would be $4.3 \times 10^{-7} \mathrm{Ci} / \mathrm{b}$, or $0.43 \mathrm{ma} / \mathrm{b}$. For the calculation of tritium absorption in fertilized food materiats, we asumed an ammonia application rate of $100 \mathrm{lb} /$ acre-year, annual rainfall of $40 \mathrm{in}$. $\left(4000 \mathrm{~m}^{3} / 2 c r e\right)$, uniform dilution of tritium, grain production of $100 \mathrm{bu} / \mathrm{acre}$ at $60 \mathrm{lb} / \mathrm{bu}$, and that the grain costained $20 \%$ moisture $a$ well $a$ the water inwolved in synthesis of carbohydrates. The concentration of tritium in ground water would be

$$
\left(\frac{100 \mathrm{~b} \mathrm{NH}}{\text { acre }}\right)\left(\frac{0.43 \times 10^{6} \mathrm{pCr}^{3} \mathrm{H}}{\mathrm{lb} \mathrm{NH}_{3}}\right)\left(\frac{4 \times 10^{\circ} \mathrm{cm}^{3}}{a c r e}\right)=0.01 \frac{\mathrm{pC}}{\mathrm{cm}^{3}} .
$$

If we assume that the rain has the recently reported ${ }^{21}$ average concentration of tritium, $500 \mathrm{pCy} /$ iter, we find that $98 \%$ of the total tritium present is contributed by rainfall.

The permissible body tissue burden of tritium, $100 \mu \mathrm{Ci}$, is equivalent to the trithum in $1 \times 10^{20} \mathrm{~cm}^{3}$ of ground water (considering only tritium from the ammonia). ${ }^{22}$ Since the fraction of water molecules in carbohydrates is about 0.6 , the concentration in grain would be approximatety

$$
0.8(0.006)+0.2(0.01)=0.0068 \mathrm{pCi} / \mathrm{g}=3 \times 10^{-6} \mu \mathrm{Cr} / \mathrm{lb}
$$

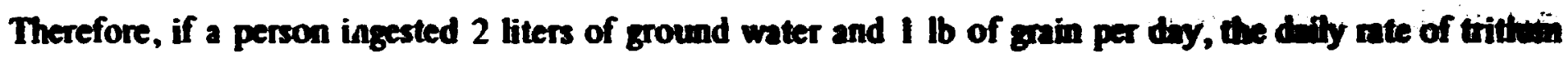
intake contributed through use of tritiated $\mathrm{NH}_{3}$ would be $2.3 \times 10^{-3} \mu \mathrm{Cr}$, moit of which would be fitim the water. This would result in a dose of 0.001 millirem/year. It appears from these calculitions thith

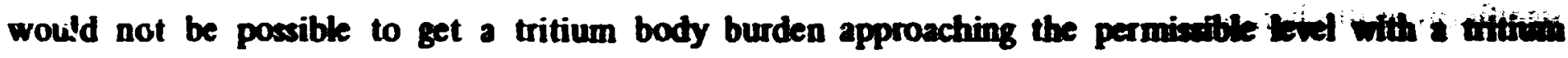
concentration several ordess of magnitude greater than the asumed value and that doses through this pathway are likely to be negtigibly small.

\section{Hydrogembed Fats and Oth}

One exposure pathway that must be considered in the use of natural gas contaminated from tritium is the use of hydrogen gas in the hydrogenation of foodetuff. The statement is made ${ }^{23}$ thet $10^{9} \mathrm{ft}^{3} \mathrm{ot} \mathrm{H}_{2} \mathrm{wm}$ used in the hydrogenation of fats and oils in 1967. If we asoume that the natural go from wich the hydrogen was produced had a tritium concentration of $1 \mathrm{pCi} / \mathrm{cm}^{3}$ and that oleic acid with a moberita weight of 282 is typical of unsaturated fats and oib, we can calculate the tritium content of the hydrogenated products. Since 2 moles of $\mathrm{H}_{2}$ are produced from 1 mole of $\mathrm{CH}_{4}$, the principl condituent of matural gas, the concentration of tritium in the hydrogen would be about $0.5 \mathrm{pa} / \mathrm{cm}^{3}$, or $1.4 \times 10^{\circ}$ $\mathrm{pCi} / \mathrm{ft}^{3}$. It follows, then, that $1 \mathrm{~g}$ of $\mathrm{H}_{2}=141 \mathrm{~g}$ of obic acid, $3.22 \mathrm{~g}$ of $\mathrm{H}_{2}=454 \mathrm{~g}$ of oleic acid $=1 \mathrm{po}=$ $1.28 \mathrm{ft}^{3}$ of $\mathrm{H}_{2}$, and $10^{\circ} \mathrm{ft}^{3}$ of $\mathrm{H}_{2}$ would contain $14 \mathrm{Ci}^{\circ}{ }^{3} \mathrm{H}$ and this would be contamed in $7.8 \times 10^{\circ} \mathrm{Bb}$ of oleic acid; thus $1 \mathrm{lb}$ of oleic acid would contain $0.018 \mu \mathrm{Ci}$.

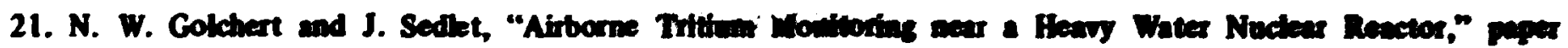
presented at the Tritiom Sympodum, Las Vege, Nev., Ave. 30-Sept. 2, 1971.

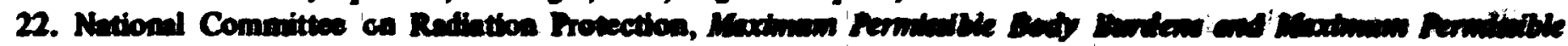

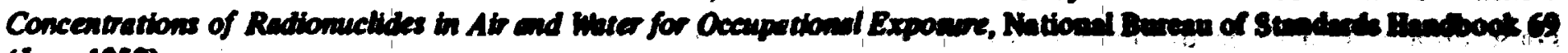
(June 1959).

23. Crem Brat Newn, 46(20) (Nov. 27, 1967). 
Therefore it would be necoserery lo retan all the tritium from 5500 is of hydrogenated product to

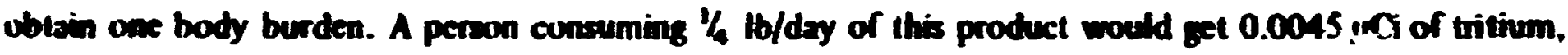
which would give a dowe or $0.0006 /$ millirem. One year's consumption at this rate would resalt in a tote dree of 0.2 millirem. Thane calculations, of course, do rot require bnowlede of lotal hydrogen comeumplion, but they do require hydrogenation of one double bond per of or fat molecule. Varialious in

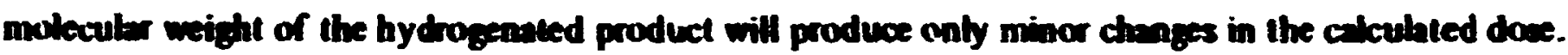

\section{Etingl Alowed}

Altwough a brge fraction of the ethyl akohol pruduced from antural gas is undoubtedly used to

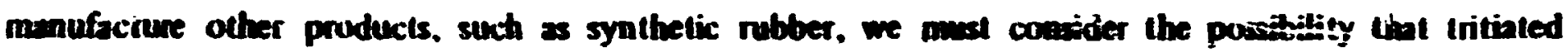
ethenul might be ingested by humen being. We hre asumed that the coataminated matural gos the chemical compuition of Gabugy gas in June 1969 (ref. 15), with an cthene concentration of 6.95\%, and that $16 \%$ of the lotal tritium $\left(1 \mathrm{pC} / \mathrm{cm}^{3}\right)$ is $\mathrm{C}_{2} \mathrm{H}_{5} \mathrm{~T}$. Then the ppatic activity of ethese $=4.5 \times$ $10^{-3} / 0.0695=0.065 \mathrm{Mi} / \mathrm{ft}^{3}, 1 \mathrm{ft}^{3}$ of ethane weigh $37.9 \mathrm{~g}$ and thes $1 \mathrm{~g}$ of ethand would contrin $1 \times$ $10^{-3} \mathrm{MCi}$ of ${ }^{3} \mathrm{H}$. A concentration of $0.15 \%$ of alcohol in the blood is a ganerally accepted defnition of intoxication level. For an average-sized individual containing 5.2 liters of blood, this correxponds to 7.8 $\mathrm{cm}^{3}$ of sloohol. If we asume that all body water hes this conceatration of aloobol, reteation of approximately $90 \mathrm{~cm}^{3}$ of alcohol would be required to intoxicate a $150-\mathrm{b}$ atult. In other words, a person drinking tritiated alcohol would pass out bons before reaching the 0.1 MCi level. In iact, it would not be powible for many people to accumulate the $100 \mathrm{~kg}$ of ethenol required to attoin a body burden of $100 \mathrm{rCr}$, even if all of thei body fluid were repinced with pure aloobol. Consumption of $150 \mathrm{~cm}^{3} / \mathrm{d}^{2} \mathrm{o}$ of liquor contuining $50 \%$ sloohol (100 proof) would result in a dose comnitment of 3.7 millineme for one year. This indicates that uritinm in tritiated sloohol at the level comidered here would not be fikety to constitute a sificant belth boerd.

\section{Oriner norimes}

Quntities of petrochemicals produced in recent years are liated in Table 1, and some of the more important ead wes of these chemicals are mentioned in the discusion of the table. Nuthough some of the compounds in Table 1 , in addition to those previoudy considered, may find use in foods or beverapes, it seems unlikely that the potential ndiation doce from buman conaumption of such products will be significantly greater then that of tritinted fats or of beverage alcohol. Other products, such as platics, recins, and anthetic rubber, would present only the posibitity of extemal ndiation. Since tritium emits cal; beta partiches with a maximum energy of $18 \mathrm{keV}$, it appeans probable that the potential dowe from all noningeted tritium-contaminated products would be nefigibly small. Their combution products could be absorbed by the body, but this is not an ortinary dipposition of most materisls menufactured from petrochemicals.

\section{DISROBTHON OF LQUIDS FYTOTHETCAUY RECOVERED FROM GASUCGY GAS}

$$
\text { Pinger Liguil }
$$

This term includes the hydrocurons and water condenaing th the gathering lines from the ges stream. Thes Hquids tend to sccumulate at low spots in the gathering hines and mut be removed periodicully so that they do not impede the flow of ges. Removal is sccomplinted by sending rubber balls (pig) through 


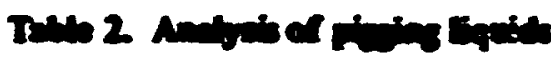

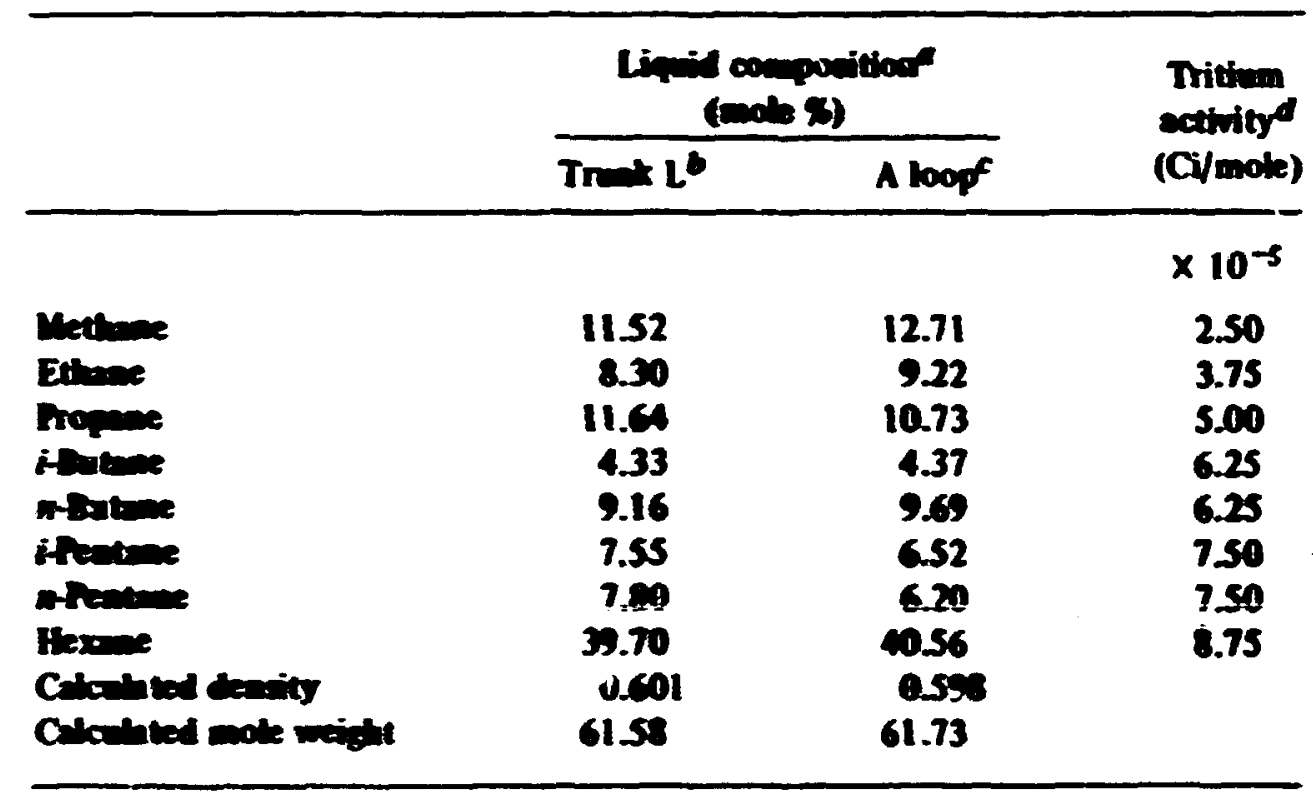

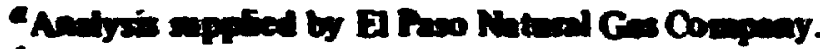

Sinne trea Nov. 20, 1962.

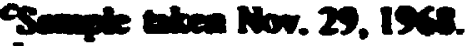

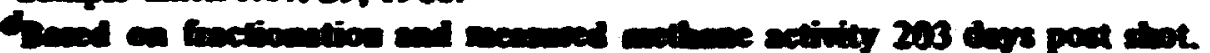

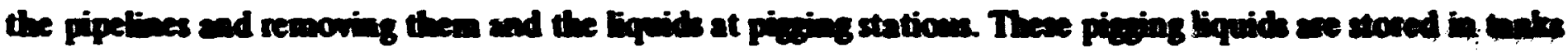
and sold to beel refinetion.

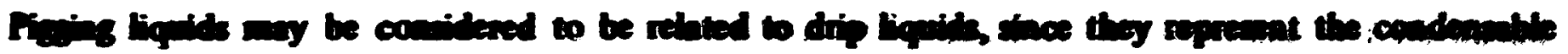

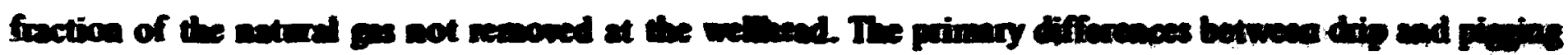

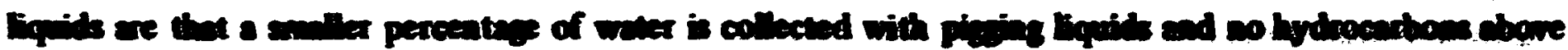

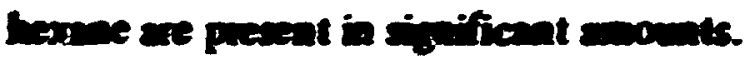

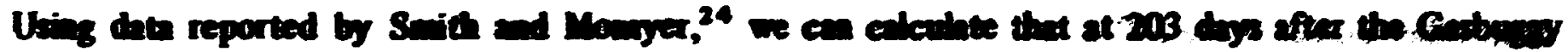

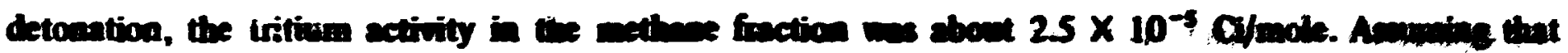

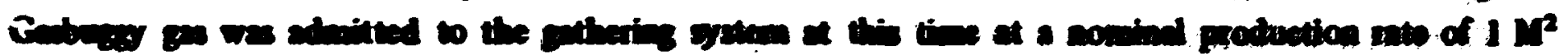

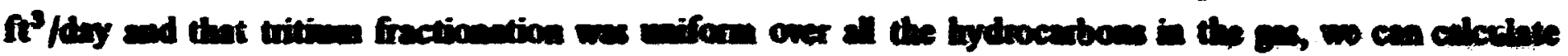

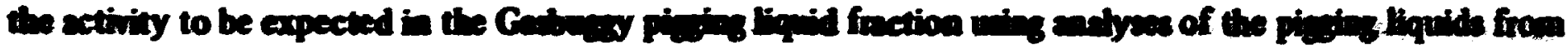

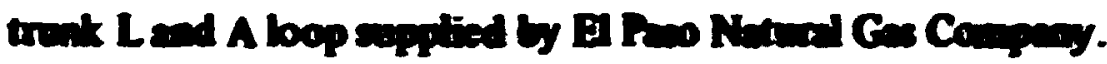

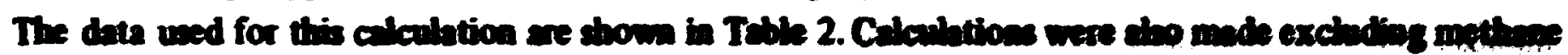

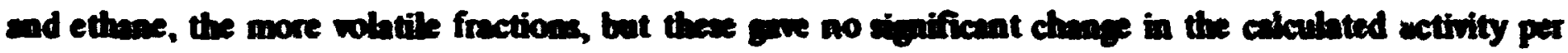
mintiver.

The expected activity does aot exceed $6.4 \times 10^{-7} \mathrm{CV} / \mathrm{ml}$. This vilue can be compared with the

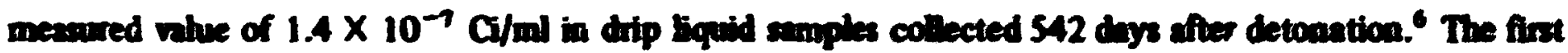

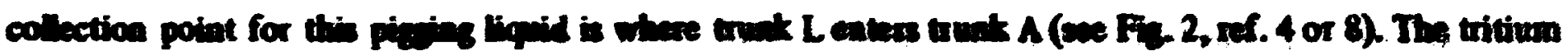

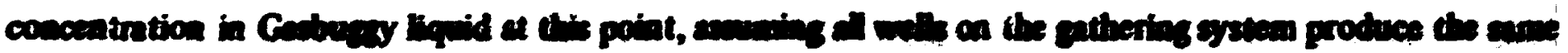

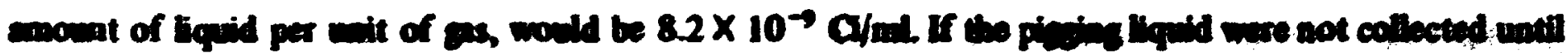

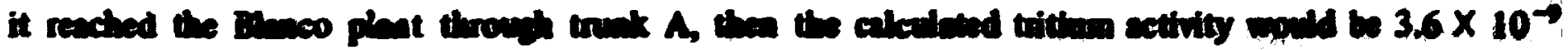
Cind

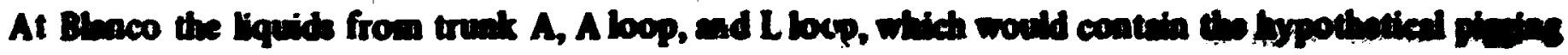

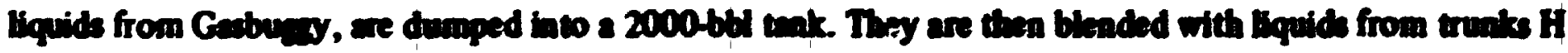

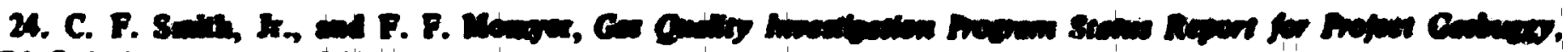
UCRL-71314 (Sepromiver ISC). 
and $\mathrm{O}$ and transferred to the Blanco tank battery, from which thay are transmitted to a local refinery through a connecting pipeline. Calcubtions indicate that the Gabursy drip liquid would not amount to more than 16 gpd; therefore the average activity in these liquids at Blanco should not exceed $1.3 \times 10^{\text {" }}$ $\mathrm{Ci} / \mathrm{ml}$.

It is of interest to note that if this liquid were burned and the water vapor formed collected as liquid water, its activity would not exared $4 \times 10^{-10} \mathrm{Ci} / \mathrm{ml}$. This is about 0.1 of the maximum allowable concentration of tritium in drinking water. 22

Normally these liquids are procesed with other petroleum fractions into galine that could be marketed outside the Sen Juen besin. The product is used a fuel for internal combustion engines, mostly in mobile equipment outdbors, where dilution and atmoepheric lispersion of the comberion products are so great that a significant rediation dose from expocure to the products of combustion of tritiumcontaminated liquids would appear to be improtable.

\section{Finat Liquide}

The liquids that are separated fron natural ox during phat procesing heve a greater radiatica dose potential then drip or piging liquids, becaure the voluse of these binids is much greater and, consequently, the toid quantity of tritium can be broer. Here, we will coasider only biquids from the

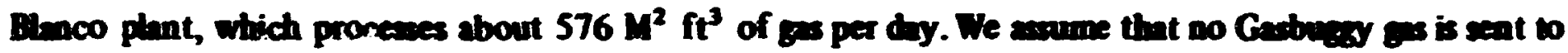
the lonecio phent.

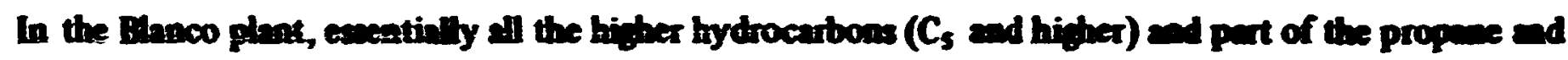

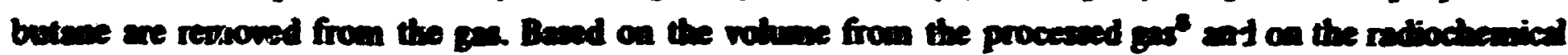

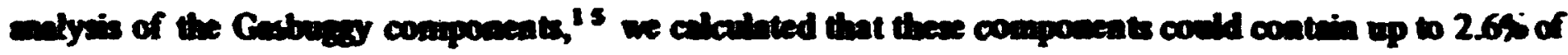

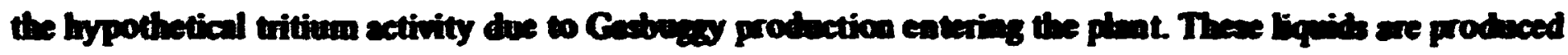

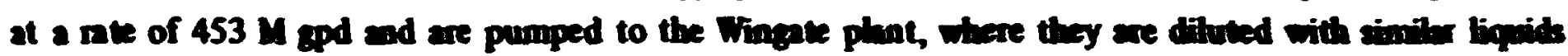

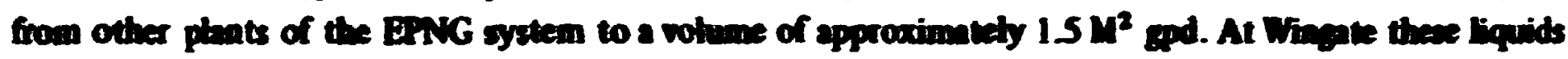

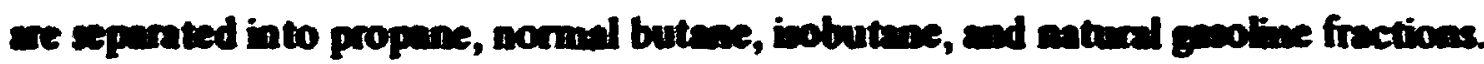

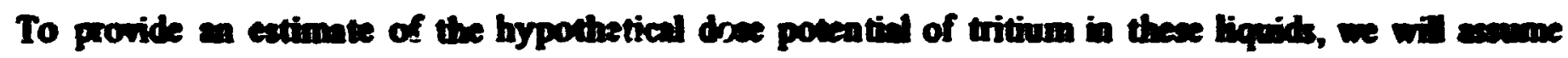

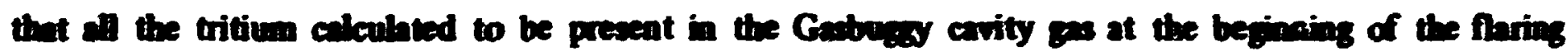
progran $(2400 \mathrm{C})$ is procesed throngh the Bheo phent durieg a period of one year. The total quatity of tritium in the liquids would then be $2400 \times 0.026=62.4 \mathrm{C}$. Thes the conceatration of tritiun in the liging after dilution in the Wingle plent would be

$$
\frac{62.1 \times 10^{6}}{1.5 \times 10^{6} \times 365}=0.114 \mu \mathrm{Cz} / \mathrm{gd}=14.6 \mathrm{pCi} / \mathrm{cm}^{3}
$$

If we further sosune that the liquid compodition can be repreanted by the formala $\mathrm{C}_{4} \mathrm{H}_{1}$, sad that the

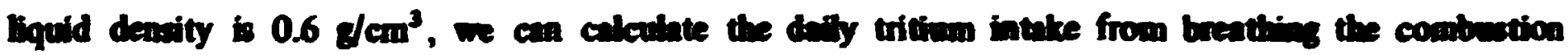
products of this liquid. Oxidation of $1 \mathrm{~cm}^{3}$ will produce $1.82 \mathrm{~g}$ of $\mathrm{CO}_{2}$. The inductud lived for $\mathrm{CO}_{2}$ is $5000 \mathrm{ppm}$, or $9 \mathrm{me}$ /liver. Therefore, $1.82 \mathrm{~g}$ of $\mathrm{CO}_{2}$ is equivient to $2.0 \times 10^{2}$ lives of it at the maximum breathing level. Since "standard man" (a typical or averese achit) breathes $20 \times 10^{6} \mathrm{~cm}^{3} / \mathrm{day}^{25}$, the dally uritum intate would be

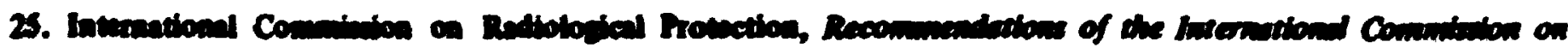

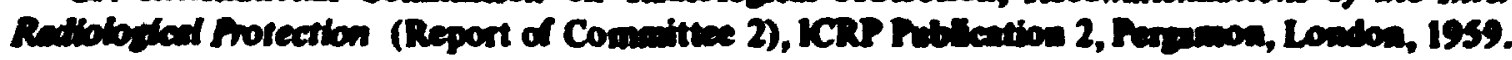




$$
\frac{2 \times 10^{4}}{2 \times 10^{2}} \times 14.6=1.46 \times 10^{3} \mathrm{pCO} \text { of HTO }
$$

Continuoves exposure at this concentration level for one year could result in a gonadal doce from inhahtion and stin absorption of approximately 0.13 millirem. Since it is rery ualikety that ayose could or would wherate coatinuous breathing of such an undesirable atmosphere, this obviounty represeats an upper limit

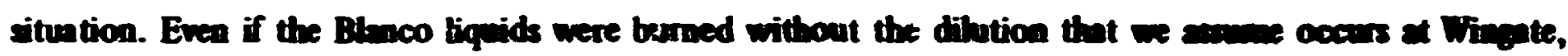
the corresponding total continuous one-year radiation done would be only 0.43 milirem.

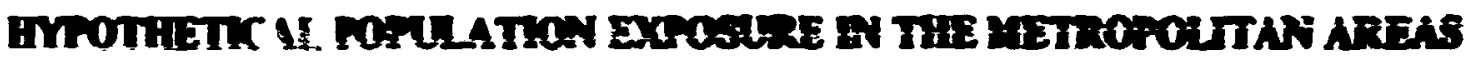

Gas from the Gesbuesy area can be processed either in the Blanco phat for trenenittol to the southern

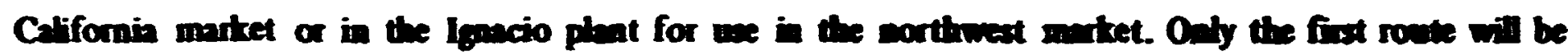

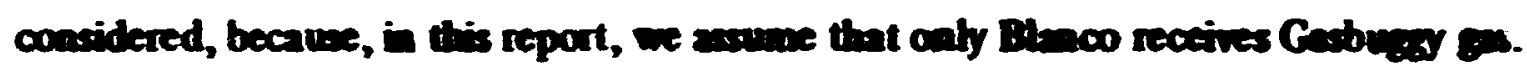

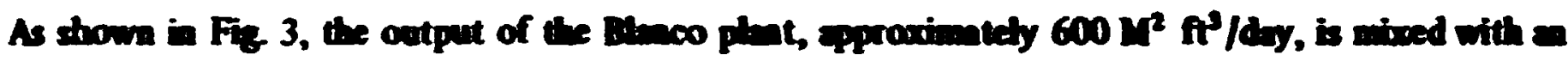

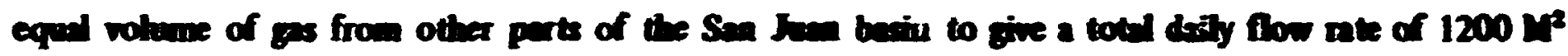

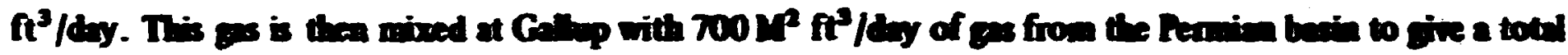

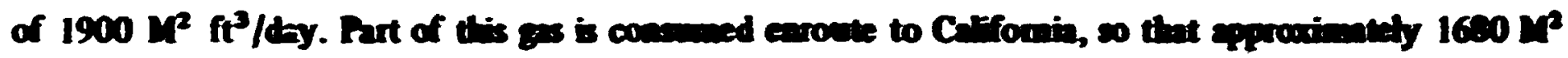

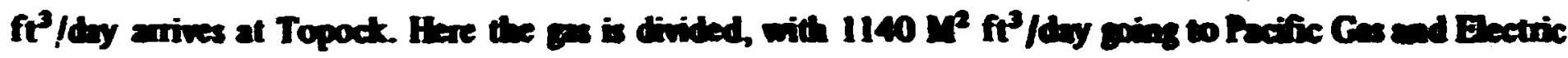

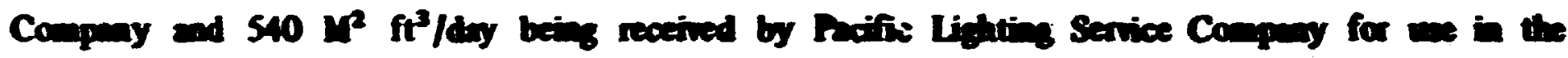

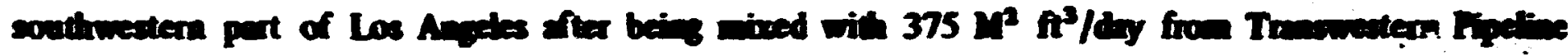

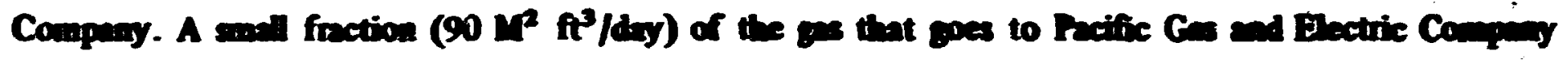

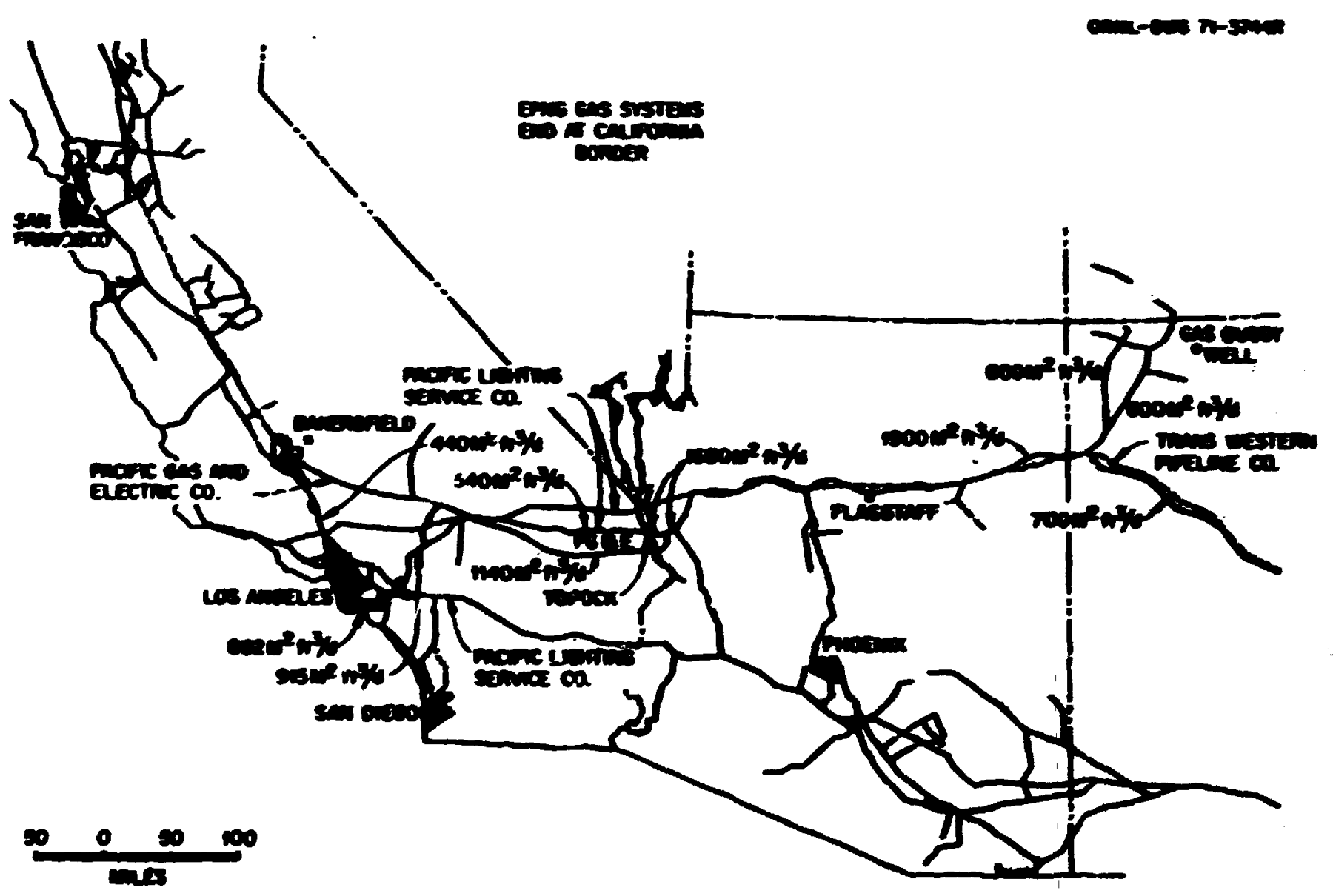

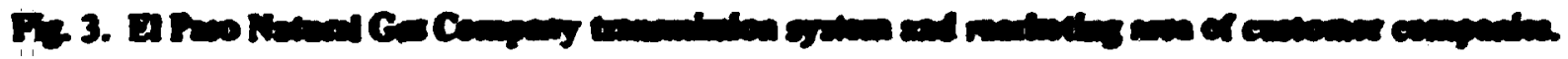




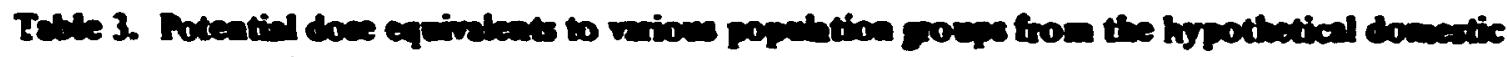

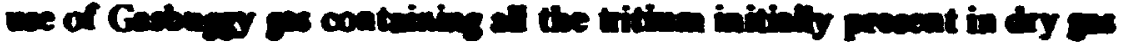

\begin{tabular}{|c|c|c|c|}
\hline City & $\begin{array}{c}\text { Heatins } \\
\text { requiremants } \\
\text { (degree-day/year) }\end{array}$ & $\begin{array}{l}\text { Further dibution } \\
\text { factor for } \\
\text { Bunco gas }\end{array}$ & $\begin{array}{l}\text { Dore } \\
\text { equivilent } \\
\text { from tritinm } \\
\text { (milirems) }\end{array}$ \\
\hline Sen Francinco & 2950 & 6.0 & 0.15 \\
\hline Fenianen cities & 2700 & 6.0 & 0.14 \\
\hline Sen Jose & 2450 & 6.0 & 0.14 \\
\hline Bakerfich & 2100 & 3.2 & 0.25 \\
\hline Frasio & 2490 & 3.2 & 0.27 \\
\hline Salinas & 2700 & 3.2 & 0.28 \\
\hline Lake Arrowhend & 5400 & 5.4 & 0.23 \\
\hline Sem Feranado Valley & 1700 & 16 & 0.05 \\
\hline Sontheatern Los Arqeles basi & 1700 & 5.4 & 0.14 \\
\hline
\end{tabular}

arrives in Los Angeles from the north after being mixed with $350 \mathrm{M}^{2} \mathrm{ft}^{3} / \mathrm{day}$ of Califomin ges. The dilution factor for Blanco arriving by this route is $440 / 90 \times 1900 / 600=16$. The corresponding factor for Almoco consumed in southeastem Los Angeles is 915/540 X 1900/600 = 5.4. Part of the hatter gas (33 $\left.\mathrm{M}^{2} \mathrm{ft}^{3} / \mathrm{day}\right)$ is wed in the resort town of Like Arrowhead, which is much colder than Los Angeles and other nearby communities.

Therefore, we here calculated the potential does for the small number of residents of this community. Table 3 summerizes data on dilution factoss applying to the tritium concentration in Blanco ges in various Califomia maket ares, the degree-days of hating required in each, and the potential dose equivalents extimated to result from the hypothetical domestic use of the Gasbrisy gos flowing at an asumed rate of 1 $\mathrm{M}^{2} \mathrm{ft}^{3} / \mathrm{dry}$ for the lifetime of the well (20 years) by individuals living full time in $1000 \mathrm{ft}^{2}$ houses of normal construction. (Averge lifetime tritium concentration $=11.7 \mathrm{pCi} / \mathrm{cm}^{3}$ entering the $\mathrm{Blanco}$ plant.) In comsidering the doses bisted in the bust column of Table 3, it should be recognized that it is asumed that the Gabuesy is dituted by a factor of 576 (rounded off to 600 above) at Btaco $\left(1 \mathrm{M}^{2} \mathrm{ft}^{3} \mathrm{gar} / \mathrm{day}\right.$ from Gabuesy) and that the total ditution factor at points of consumption ranges from 1843 to 9216 . Such high dilution factors would not prevail if an entire fiekd were deneloped by nuclear stimulation and the gas was ued to supply the southern Califomia maket. However, the total demand of this maket is so brge and it is growing so mpidly that it seems very unlikely that a single nuclearly stimulated field would supply a brge fraction of the total requirements of this market. Also, as was discumed earlier in this report, nuclear explosives that will be ued in brge-scale application of this technique win' slmost certsinly produce much less tritium than the Gasbuses and Rulison explosives. Until more quantitative data from future nuclear atimubtion become avaibble, there seems to be mo reason to change our eartier decision to we 1 $\mathrm{pC} / \mathrm{cm}^{3}$ for the tritium concentration in natural gas at the point of consumption.

Natural gas is used in metropoliten area for fueling steam plats to generece electricity and for a wide vriety of industrial and commercial applications, a well a for domeatic consumption. Combustion products released from steam plants through tall stacks represent elevated point sources, while releases from most of the industrial and domeatic wes can be considered to be spread uniformbly over a sizable area of ground surface. Models have been developedis-2s to deccribe the dispersion of pollutants from

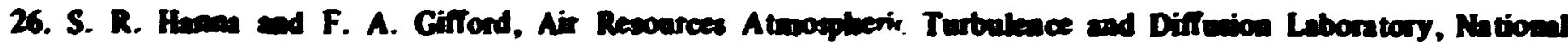

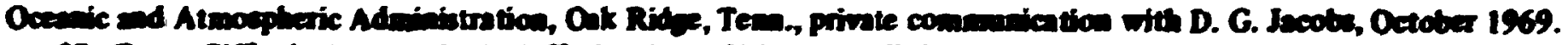

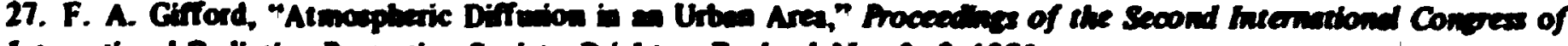

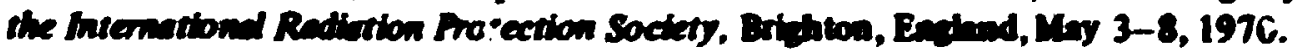

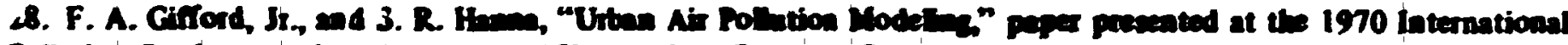
Air Pollotion Confereace of the International Union of Air Pollation Prevention Ascociation. 


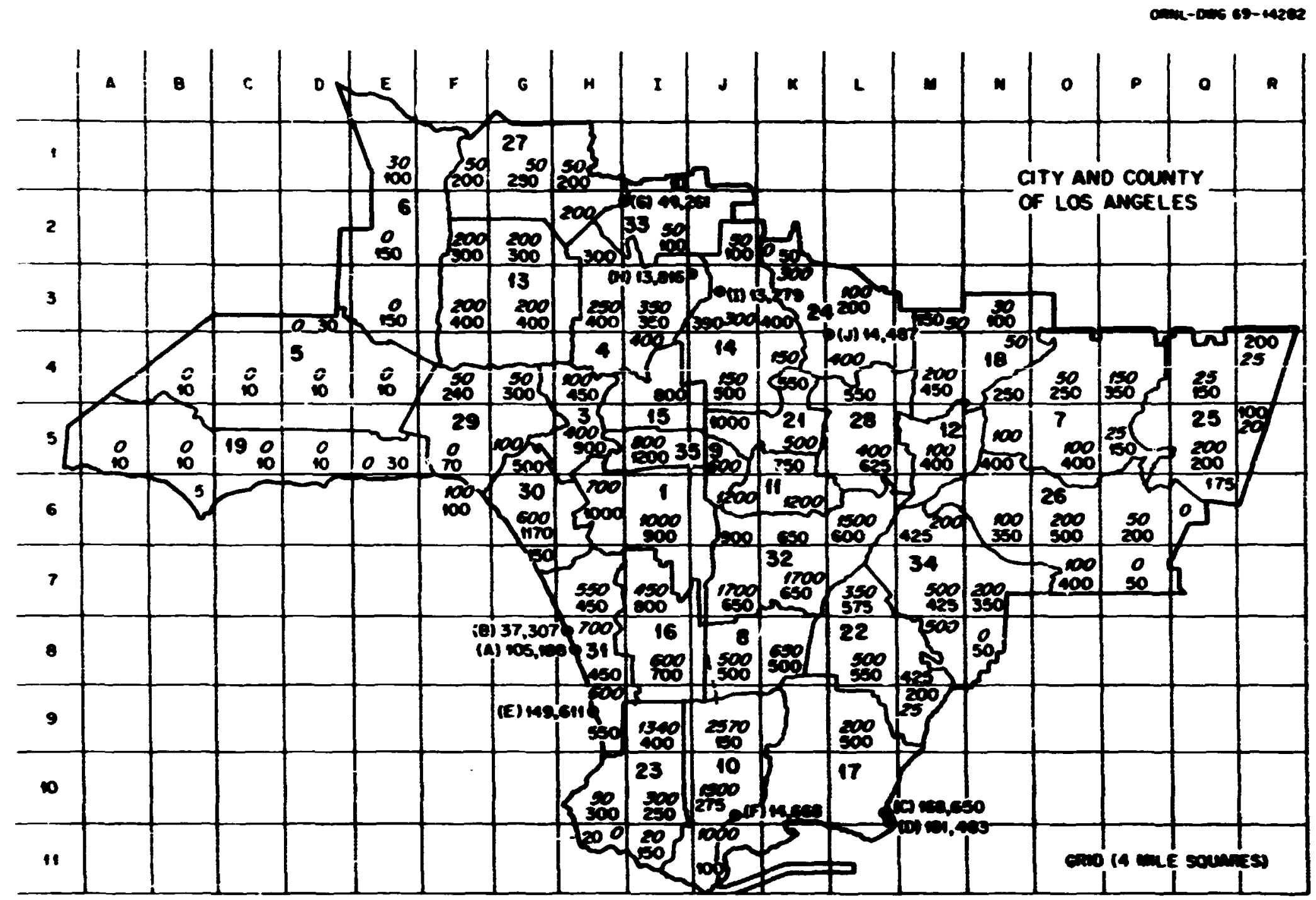

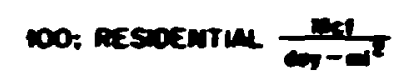

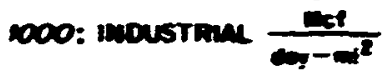

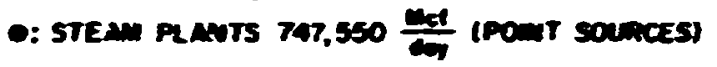

29: 105 anecles countr man statrstical areas

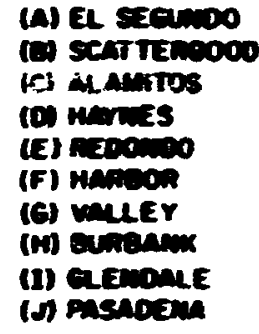

ia sentrancoos

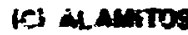

(E) Ringers

(G) ruef

(d) Pussocon

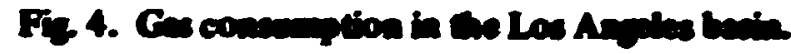

groundtevel area sources in metropolitan areas. Data are introduced into the computer progrem in a grid format 2 described in Appendix A. This program can be ued to compute the groundterel atmoopheric concentration of any type of pollutent, including radionctivity, for ground-evel area sources. On this the concentrations of pollutant relesed from elevated point sources are superimponed. The computer code for both types of release uses local meteorological conditions for determining the groundtenel air concentration of pollutants. The results of calculations for the Los Angeles besin were compared with the results of similar calculations based on a model developed by Lamb," and it was conchuded that the Atmospheric Turbulence Diffuion Laboratory (ATDL) model gave areasource concentration values higher than Lamb's by a factor of 2, which is cosaidered rescombly good agreement for this type of calculation. No conchusion 28 to which model gives the best values could be dram. Ground bevel ir concentrations for the combustion products from natural gas in the Los Angeles besin and in the San Frenciveo Bay area given

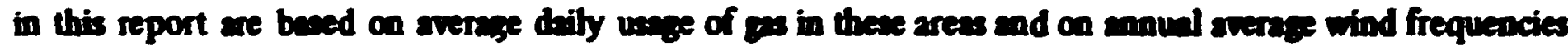
and wind speed. They are expressed in terms of cubic centimeters of natural ger per cubs: meter of air.

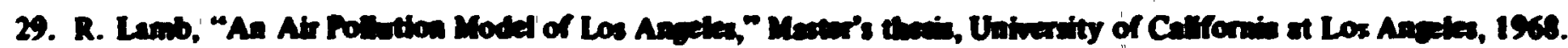




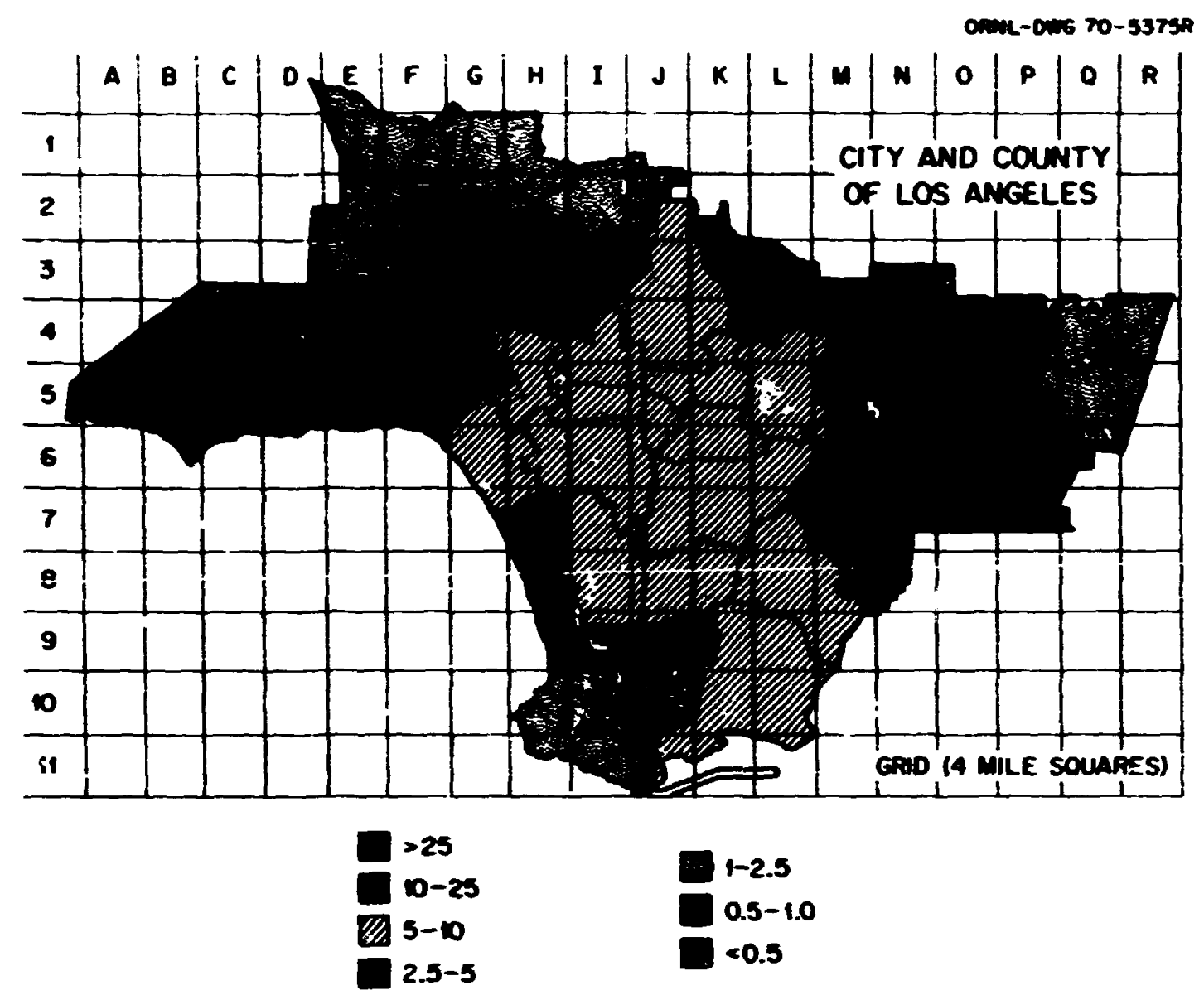

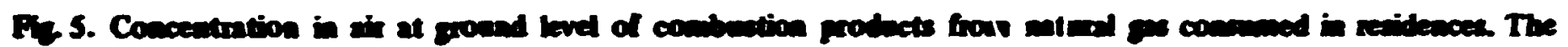
concentuntion is expresed is the equivalent content of the combustion products from the ens in colbic centimeters per cobic meter of air.

Figure 4 shows ges uage data for Los Angeles, including the location of ga-fired electric generating plants. Figure 5 shows values for residential sources in the Los Angetes area, and Fig. 6 shows the corresponding data for induntrial sources. These two area sources of release were combined with the releases from stacks to provide the data in Fis. 7. Since bes detailed data on gas unge were available for the San Francisco area, only total ground-tevel gas unge and elevated scuice values are shown in Fig. 8; Fig. 9 shows the combined effect of both types of release.

In the Los Angeles basin there are three grids that have quite high concentrations of combustion products in the air at ground level due to large releases from tall stacks. The peak concentration of combustion products in the air at gound level was eatimated to be equivilent to the amount produced from combustion of $100 \mathrm{~cm}^{3}$ of natural gas per cubic meter of air; thus, if the gas being consumed has 2 concentration of $1 \mathrm{pCi} / \mathrm{cm}^{3}$, the groundtevel concentration in this gid would be $100 \mathrm{pCi} / \mathrm{m}^{3}$. It is eatimated that the population-weighted mean concentration would be $13 \mathrm{~cm}^{3} / \mathrm{m}^{3}$ in the Los Angeles basin. In the San Francisco Bay area the peak concentration is due primarily to ground-evel sources and is extimated to be $13 \mathrm{~cm}^{3} / \mathrm{m}^{3}$. The population-weighted mean concentration is estimated to be $3.7 \mathrm{~cm}^{3} / \mathrm{m}^{3}$.

The potential dose equivalents that could be attained from the use of natural gas having a concentration of $1 \mathrm{pCi} / \mathrm{cm}^{3}$ of tritium in these two major metropolitan areas are given in Table 4. From these respective extimates it is sen that the major exposure would be due to domestic consumpticn of gas in houses equipped with unvented space heaters.

In considering the dose equivilents in Table 4, we must remember thet, although these hypothetical radiation doses are very much less than 170 millirems/year, the une of :atural gas from nuclearly stimulated wells represents only one potential source of population radiation exposure. Also, in this preliminary analysis only direct modes of exposure through inhalation, immersion, and abeorption through the skin 


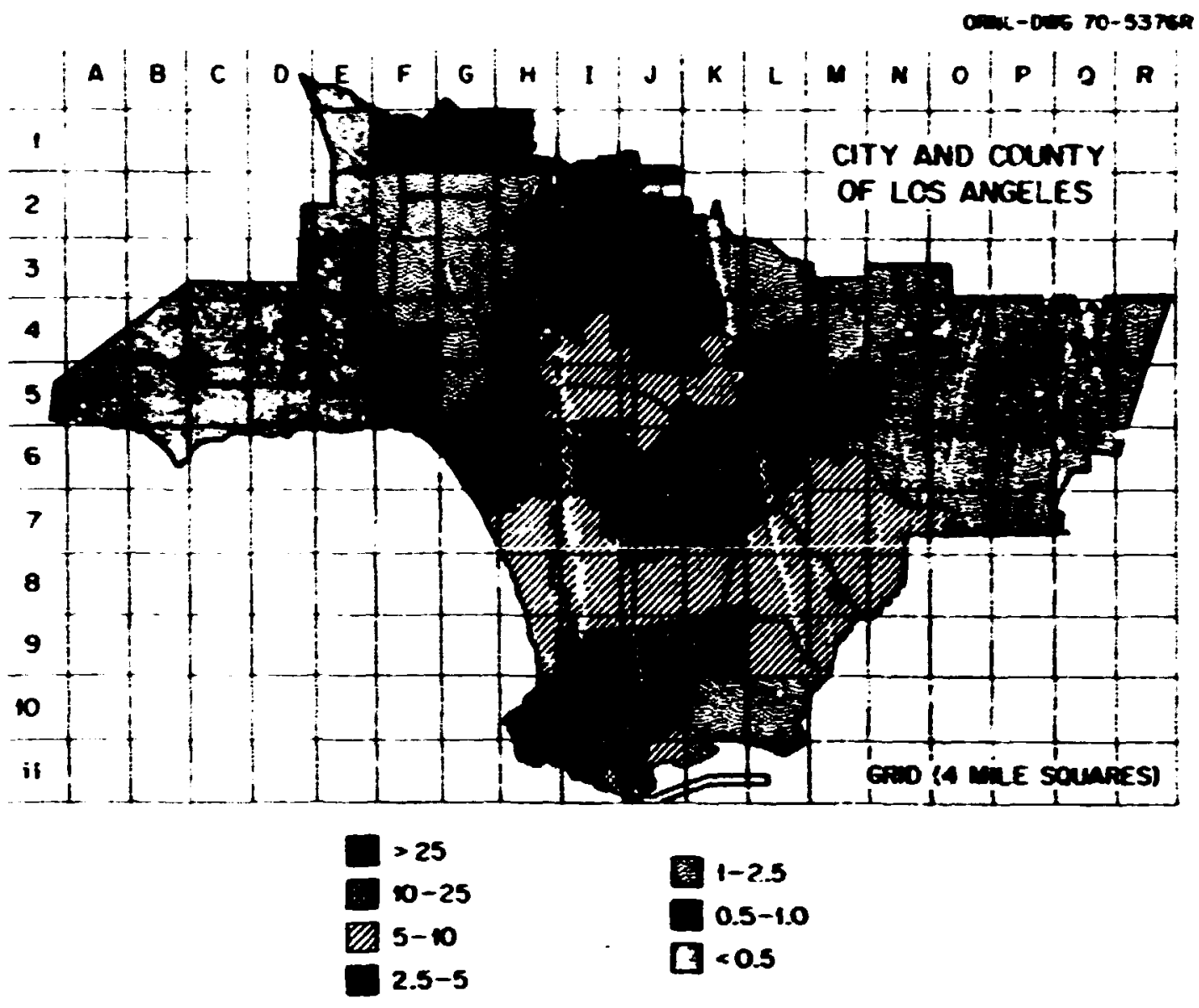

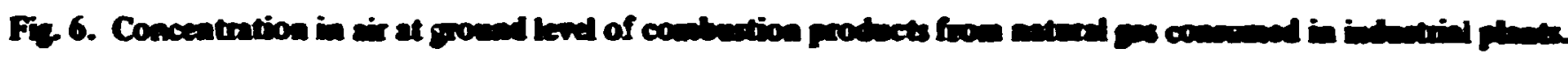

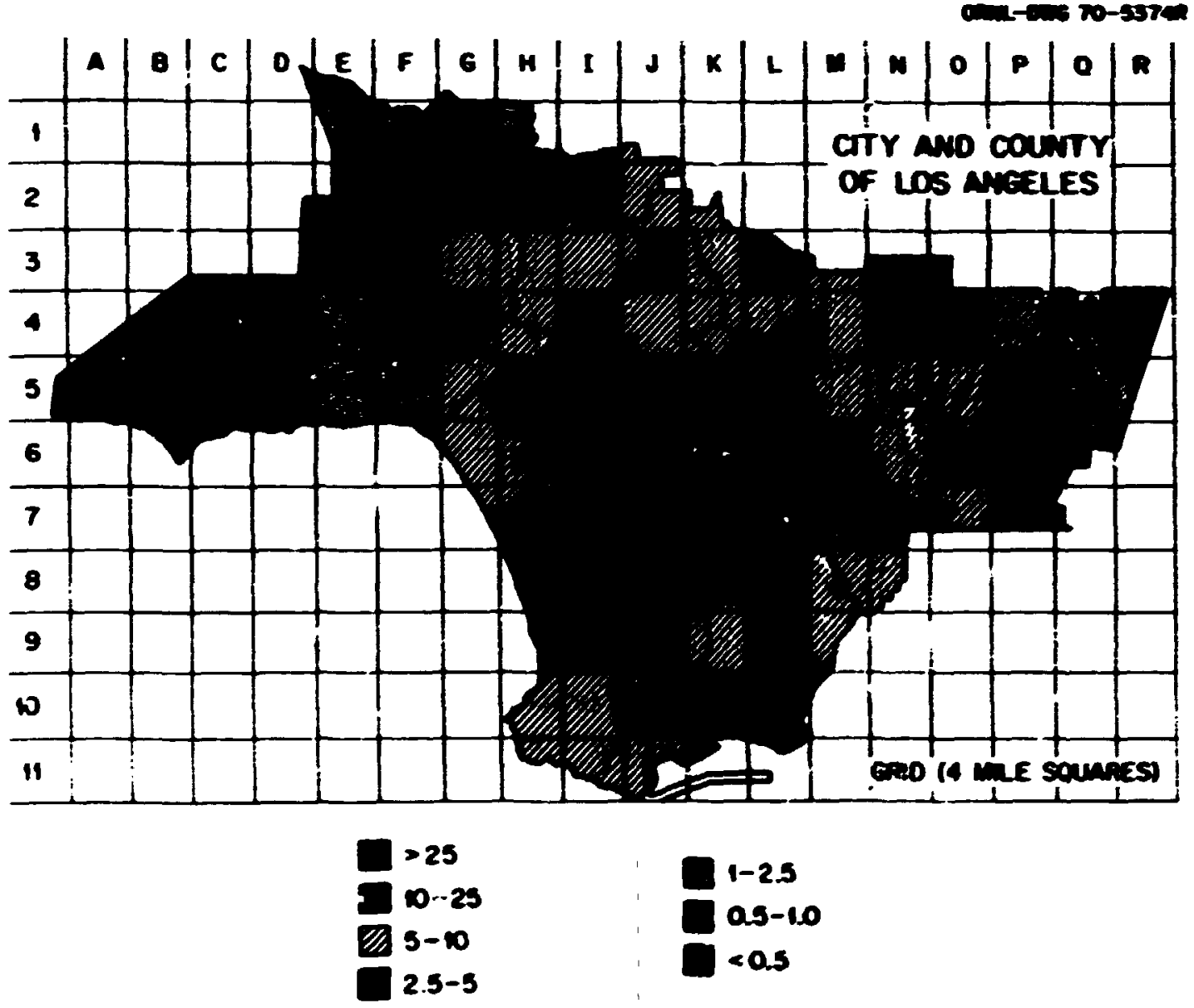

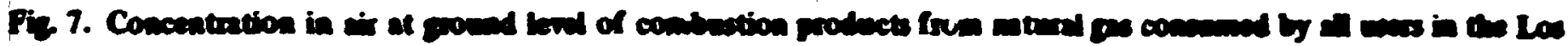
Anples aren. The concestration is expresed as the equivalent content of the combustion products from the pas in cabic centimeters per cobic meter of at. 


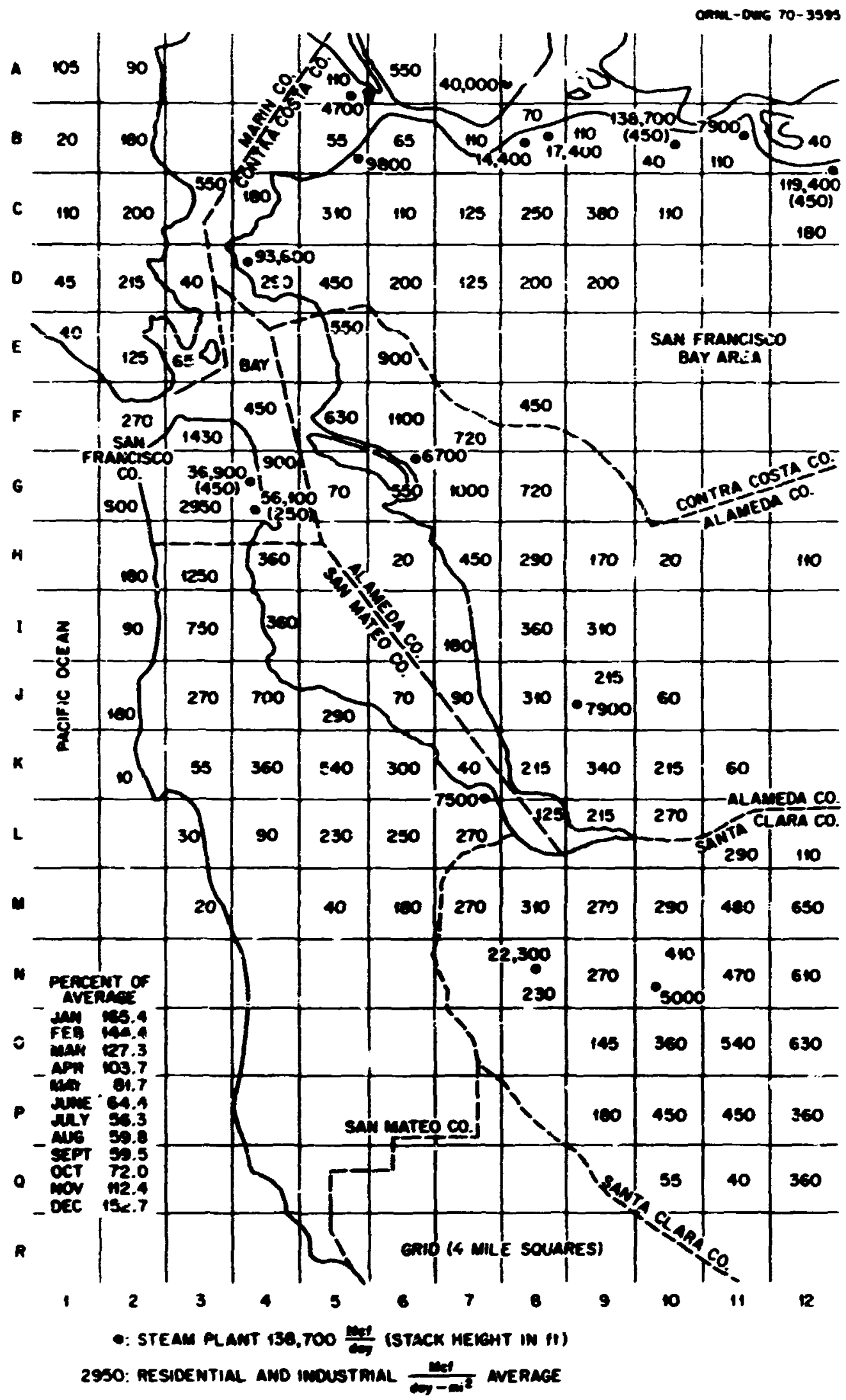

Fiz. 8. Gas consumption in the San Franciaco Boy area.

have been considered. The recommendations of the ICRP and other authorities require that radiation exposures from all sources, other than natural background and medical sources, be considered in any radiological safety evaluation. ${ }^{22,25,30}$ Furthermore, these potential doses could involve many millions of people; $s 0$ extreme caution should be used in establishing "permissible" concentrations of man-made radioactivity in natural gas that would be considered acceptable for industrial and domestic consumption.

30. Federal Radiation Council, Background Material for the Devebopment of Radiation Protection Standards, Federal Radiation Council Report No. 5 (July 1964). 


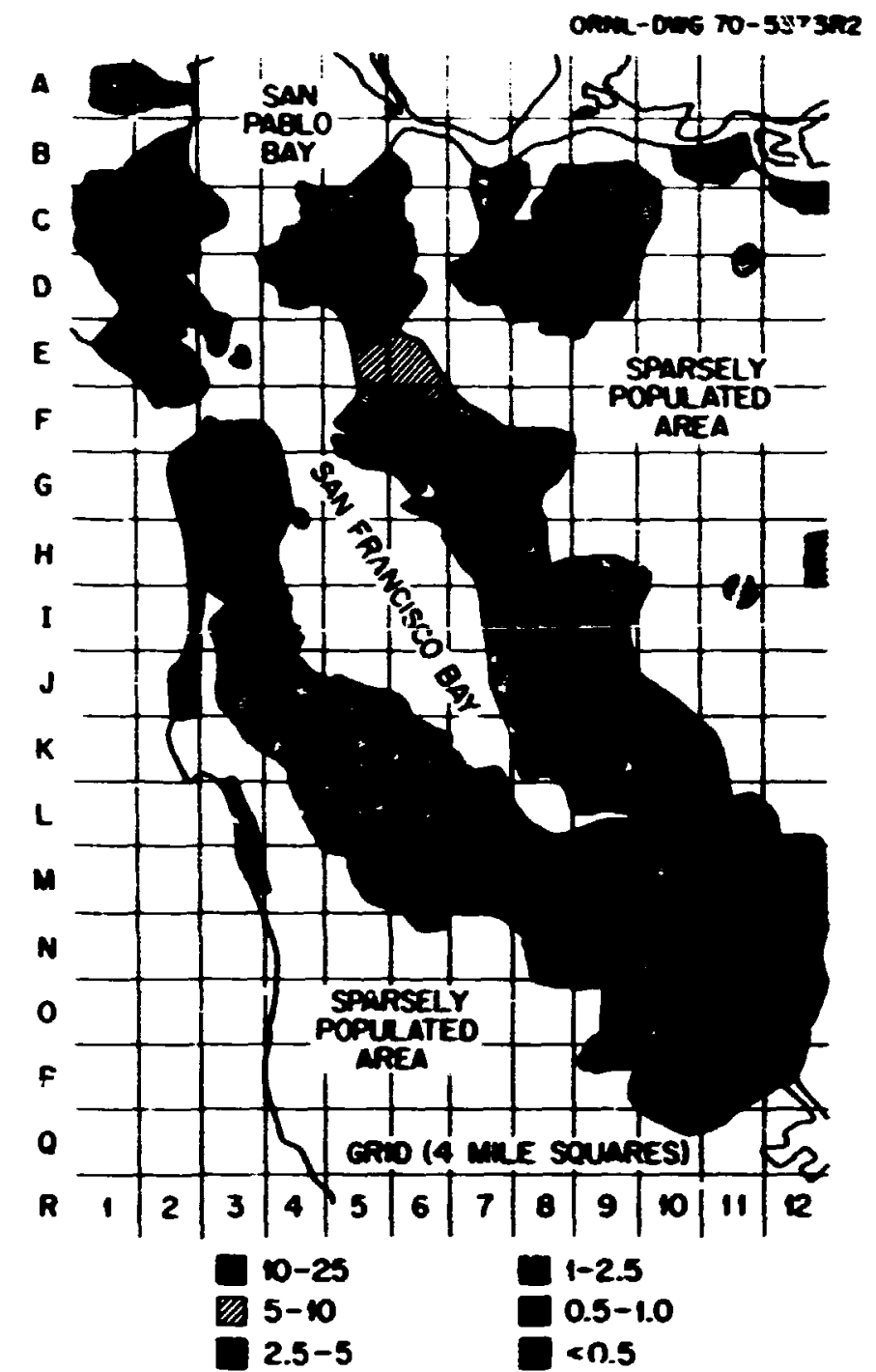

COAKENTRATION OF COMBUSTION PROOUCTS FROM MATURAL GAS IN AIR AT THE GROUND SUAFACE. THE CONCENTRATION IS EXPRESSED AS THE EOUTMLLENT CONTENT OF THE COMBUSTION PROOUCTS FROM THE GAS IN CM PER CUBNC METER OF AR.
Pie 9. Concentudion in tis at round bon of combention

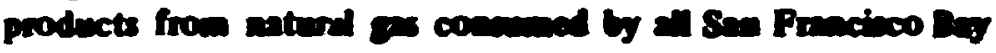
ares The concentration is expresied as the equirilent cos. tent of the conbustion products from the pa in cubic centimeters per cubic meter of air.

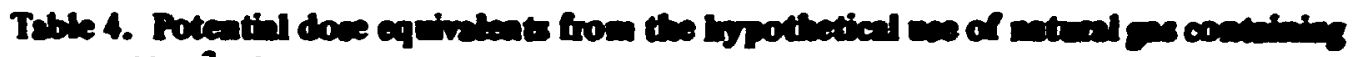

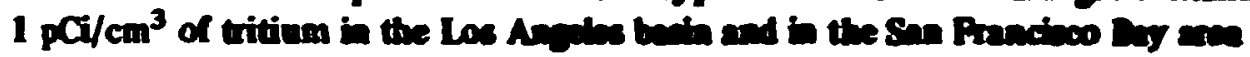

\begin{tabular}{llc}
\hline & \multicolumn{2}{c}{ Dose equivalents (milliremi/year) } \\
\cline { 2 - 3 } & Los Angeles besin & San Francisco Bay area \\
\hline Atmosphere & & \\
At point of peak concentration & 0.19 & 0.024 \\
Popubtion weighted average & 0.024 & 0.007 \\
Domestic use & & 1 \\
Nonvented heating and appliancese & 2.0 & 2.5 \\
All appliances vented except range & 0.27 & 0.27 \\
Weighted average $b$ & 0.45 & 0.49 \\
Total & & 1 \\
Maximum dose equivalents & 2.2 & 2.5 \\
Weighted average dose equivalents $b$ & 0.47 & 0.50 \\
\hline
\end{tabular}

ascumes 1700 desdays of heating for Los Angelos and 2950 for San Francieco and a 1000-it ${ }^{2}$ residence of normal construction (see ref. 8, Appendix B), hoving ose atr chence per hour. Although recent data (R. H. Blichs and C. E. Weneman, "Naturl Ventilition of Modern Tightly Constructed Homes," paper presented at the Americas Sas Arocintion Institute of Cas Technoloyy Conference on Natural Gas Rewarch and Techaolosy, Chicapo, III., Feb. 28-Mar. 3, 1971) indicate that tight homes can hrve rates as bow 28 0.5/w, homes of this type would almost certuinly have vented pace beathas systems.

b Ascumes nonvented heating for $10 \%$ of the population. 


\section{HYPOTHETICAL USE OF NUCLEARLY ST IMUATED GAS IN A LARGE ELECTRK PLANT IN LOS ANGELES}

Modern electric generating stations depend on large capacity for econonic performance. A typical plant has a supercritical steam cycle with an overall station efficiency of about $\mathbf{4 0 \%}$. delivering approximately $1000 \mathrm{MW}$ of electric power. This corresponds to $2500 \mathrm{MW}$ of input thermal energy. If natural gas at 1100 Btu/ft $\mathrm{ft}^{3}$ is used as the fuel, the daily requireinent for such a plant is $185 \mathrm{M}^{2} \mathrm{ft}^{3}$. We will assume, for simplicity, that the gas delivered to the plant contains $1.0 \mathrm{pCi}$ total tritium and $1.0 \mathrm{pCi}$ of ${ }^{85} \mathrm{Kr}$ per cubic centimeter $\left(0.028 \mu \mathrm{Ci} / \mathrm{ft}^{3}\right)$ respectively. At this concentration the daily release rate is comparable with the reported average release rate from $1000-\mathrm{MH}$ (e) pressurized-water nuclear power plants of 10 to $20 \mathrm{Ci} / \mathrm{day}$, primarily to surface waters.

The assumed tritium to ${ }^{85} \mathrm{Kr}$ ratio of $1: 1$ is close to the actual ratio of these impurities in Rulison gas of 1.17:1 reported by Smith ${ }^{14}$ for preflaring gas jampies.

Meteorological analysis for a given location and stack height is required in order to estimate the exposure from the hypothetical use of nuclearly stimulated gas in a steam plant. Dilution factors have been estimated for a plant located in Los Angeles, using $185 \mathrm{M}^{2} \mathrm{ft}^{3}$ of gas daily. ${ }^{31}$ The stack height of $450 \mathrm{ft}$ (137 $\mathrm{m}$ ) assumed in these calculations is ty pical of the large electric plants in Los Angeles that use natural gas as fuel. Detaik of the calculations are given in Appendix B.

The daily output of radioactivity of $5.3 \mathrm{Ci}$ each of tritium and ${ }^{25} \mathrm{Kr}$ is equivalent to $6.1 \times 10^{-5} \mathrm{Ci} / \mathrm{sec}$.

The calculations sinow that for Pasquill's " $\mathrm{C}$ " type of turbulence, ${ }^{32-34}$ with slightly unstable weather conditions, the maximum concentration of tritium or ${ }^{85} \mathrm{Kr}$ at a distance of $7000 \mathrm{~m}$ from the plant would be $3 \times 10^{-6} \mu \mathrm{Ci} / \mathrm{m}^{3}$. At this tritium concentration, an average adiut might receive a gonadal dose of 0.005 millirem/year from inhalation and absorption through the skin. The equivalent gonzdal dose from ${ }^{85} \mathbf{K r}$ would be about $10^{-5}$ millirem.

For the "worst possible" meteorological situation in the Los Angeles terrain, a stable plume meandering through an occupied pass at its final level under heavy inversion conditions (Pasquill's "F" category), the calculations show that at $10,000 \mathrm{~m}$ from the plant the maximum concentration of tritium or ${ }^{85} \mathrm{Kr}$ would be $7.5 \times 10^{-4} \mu \mathrm{Ci} / \mathrm{m}^{3}$. Even if exposure under these unusual conditions continued for a period of one year, the resulting gonadal dose from tritium would be only 1.3 millirems. The skin dose from ${ }^{85} \mathrm{Kr}$ would be 1.5 millirems, which is equivalent to a gonadal dose of about 0.017 millirem.

Appendix A

\section{THE ATDL AREASOURCE MODEL ${ }^{28}$}

\section{F. A. Gifford, Jr. S. R. Hanna}

A simple model of urban air pollution, based on reasonable first principles and incorporating some attempt at rigor, is presented below. The result, a simple, easily applied areasource concentration formula, has been compared with several of the previous formulas, and the conclusion is that it performs well.

First, we assume that the problem of urban air pollution can be simplified by considering separately the isolated point sources such as tall stacks and lumping the contribution of the multitude of lesser sources of

31. W. M. Culkowki, Air Resources Atmospheric Turbulence and Diffuion Laboratory, communication with C. J. Barton, ORNL, May 1970.

32. D. Sbde, ed., Meterology and Atomic Eneryy, 1968, TID-24190 (1968).

33. G. A. Brimgs, Flume Rise, AEC Critical Review Series Report, T1D-25075 (November 1969).

34. F. Pasquill, Atmospheric Diffucion, Van Nostrand, Princewon, NJ., 1962. 
all types into a spatially variable area-source concentration $X_{A}$. This is assumed to obey the steady-state diffusion equation in iwo independent variables,

$$
u(z) \frac{\partial X_{A}}{\partial x}=\frac{\partial}{\partial z} K(z) \frac{\partial X_{A}}{\partial z},
$$

where the mean wind $u(z)$ blows in the $x$ direction. Neglect of the $y$ component of the diffusion is equivalent to the observation that point-source plumes in the atmosphere tend to be long and narrow, and so the concentration at a point can be influenced only by sources in a narrow, plume-chaped upwind section (see ref. 31). If $u$ and eddy-diffusivity $K$ are assumed to obey the usual power iaws,

$$
\begin{aligned}
& u(z)=u_{1}\left(\frac{z}{z_{1}}\right)^{m}, \\
& K(z)=K_{1}\left(\frac{z}{z_{1}}\right)^{n},
\end{aligned}
$$

the "partial" solution to Eq. (1) for the ground tevel concentration distribution $X_{1} O$ due to an area source has been shown by Gifford ${ }^{35}$ to be

$$
X_{1 O}=\frac{2_{1}^{m}}{c_{1} u_{1} B(1-s)}\left(\frac{\Delta x}{2}\right)^{1-s}\left\{Q_{0}+\sum_{i=1}^{N} Q_{i}\left[(2 i+1)^{1-s}-(2 i-1)^{1-s}\right]\right\},
$$

where $s=(m+1)(2+m-n)$ and the distance $x$ from the receptor point to the upwind edre of the city is given by $x=(N+1 / 2) \Delta x$, where $N$ is the number of upvind grid equares in the scource inventory and $\Delta x$ is the grid size as given by the usual "checkerbourd" sourceinventory pattern. Source strength $Q$ is constant for each square. The receptor point is assumed to be located at the center of s mource square. There is no particular difficulty involved in adapting the model to other geometries, including inegular areatource patterns.

The parameter $B$ depends on the vertical concentration distribitivn. The total concentration distribution $X_{A}$ is related to the ground-tevel value $X_{1} O$ by

$$
x_{1}=x_{10}(x) f\left(\frac{2}{2}\right)
$$

Here the reference height $Z$ ementially represents the "top" of the polluted air and incresses with distance from the upwind edze according to the formula

$$
Z=c_{1} x^{1 /(2+m-n)}
$$

This assures that a "variables separable" solution of the type of Eq. (5) will satisfy Eq. (1). Then, with $\}=$ $2 / Z$, the value of $B$ follows from the continuity condition

$$
\int_{0}^{-} u(z) x_{1}(x, z) d z=\int_{0}^{\infty} Q(x) d x \text {. }
$$

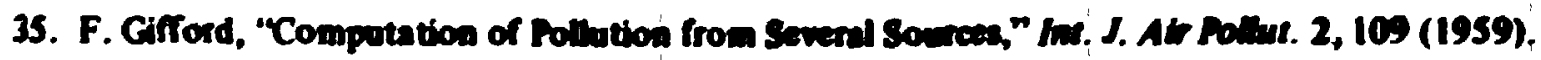


From this and Eq. (5),

$$
B=\int_{0}^{-} \zeta f(\zeta) d \xi
$$

The constant $c_{1}$ is determined from the relation $c_{1}=3 d^{1 /(m+1)}$, where $e$ is defined by the usual powertaw formula for the standard deviation of the vertical concentration distribution

$$
\sigma_{2}=a x^{b}
$$

and $Z \cong 3 \sigma_{2}$. Values of $a$ and $b$ based on extensive observational data have been summarized by, for instance, Slade ${ }^{32}$ and Smith. ${ }^{36}$

Taule A.1.

\begin{tabular}{lcccc}
\hline Meteorological cosditions & $a$ & $b$ & $(1-b)$ & $(1-b)$ \\
\hline Very unitable & 0.40 & 0.91 & 0.09 & 0.036 \\
Unstable & 0.33 & 0.86 & 0.14 & 0.046 \\
Neutral & 0.22 & 0.80 & 0.20 & 0.044 \\
Estimated Paquill "D" & 0.15 & 0.75 & 0.25 & 0.037 \\
Stable & 0.06 & 0.71 & 0.29 & 0.017 \\
\hline
\end{tabular}

Table A.1 is based on the values given by Smith ${ }^{36}$ and includes our extimate of the value cortesponding to Pasquill's "D" (slightly stable) condition. We believe that this value is more appropriate to urban conditions than Smith's "stable" value. Unfortumately, few data are as yet. available on diffusion over cities. For a Gausian vertical distribution, with the above ascumptions,

$$
B=\frac{1}{3}\left(\frac{\pi}{2}\right)^{1 / 2}
$$

for a linear decrease in concentration, $B \cong 0.4$. In general, it is unlikely that $B$ will differ much from these values.

Equation (4) can be generalized in the usual ways, by introducing wind direction and speed frequency class intervals and varying the meteorological parameter s. The only real problem that arises in the extension of Eq. (4) to the case of annual average concentrations is that of adapting the basic rectilinear source config ration to radial wind directions other than the cardinal ones. Our arbitrary but simple scheme for doing this is illustrated in Fig. A.1.

36. M. E. Smith, ed., Recommended Gulde for the Prediction' of the Dispersion of Airtome Efficuents, Ist ed., Amerian Society of Mechanical Engineers, New Yort, May 1968. 


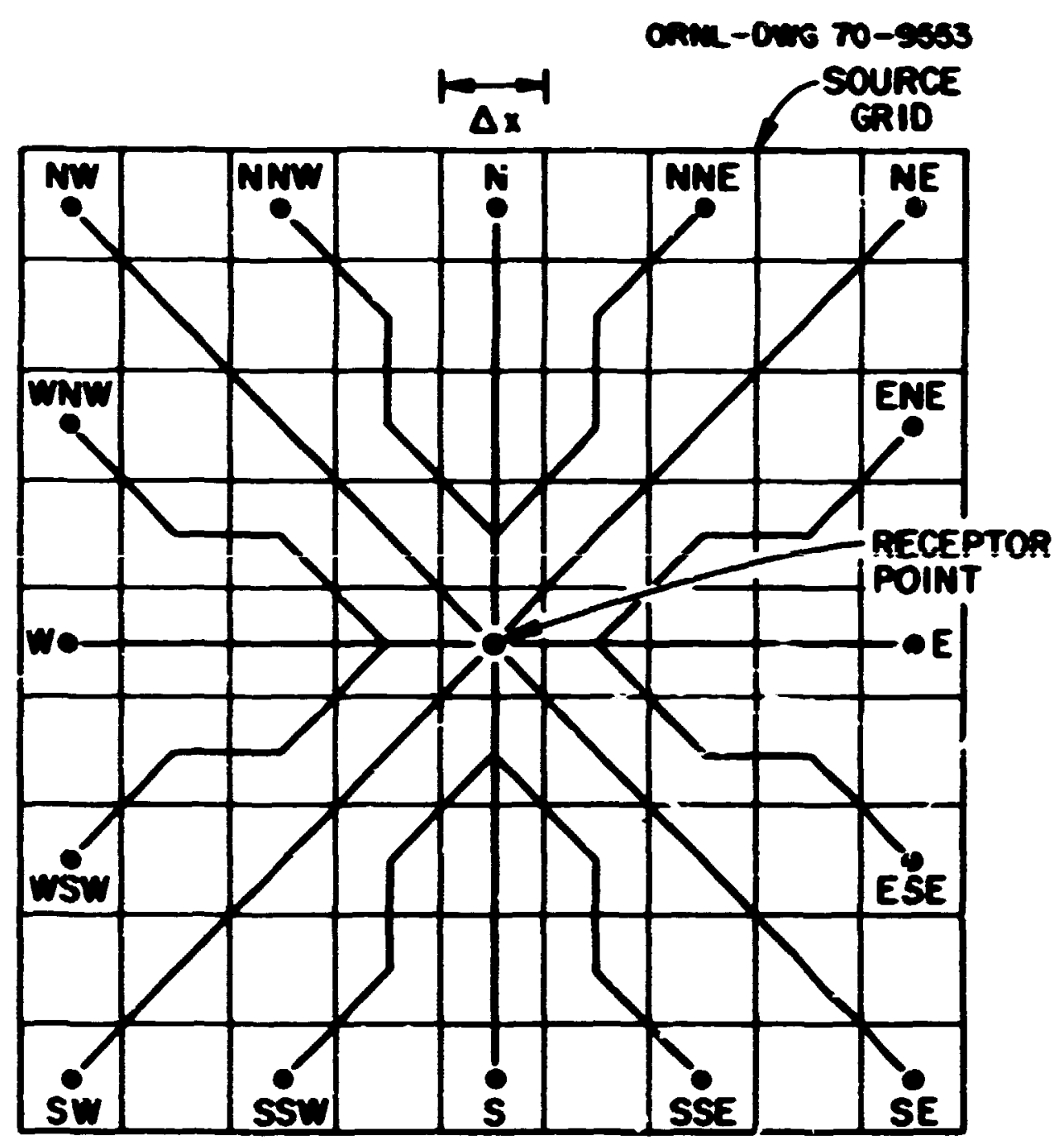

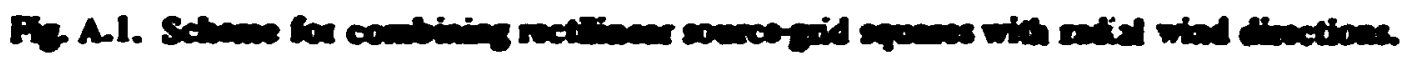

\section{Appeadix B

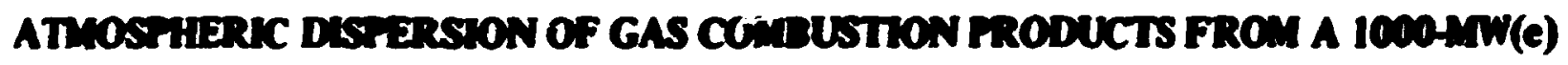 ELECTRIC GENERATING MANT IN LOS ANGELES ${ }^{31}$ \\ W. M. Culkowiki}

Plume rise is assumed to be described by equations in Metcorolosy and Atomic Enersy. 32 namely, $\Delta h=400 \mathrm{~F}^{-3}$ (neutral conditions, atmoephere well mixed because of vigorous, turbulent mixing. Temperature decrease of adisbatic lapere rate of $5.4^{\circ} / 1000 \mathrm{ft}$ ).

$\Delta h=2.6(F / u)^{1 / 3} S^{-1 / 3}$ (stable conditions, temperature lapee of the atmosphere less than the adiabatic bpoe rate. Air lifted adiabatically tends to sink back).

$i h=2.0 F^{-1 / 3} u^{-1} x^{2 / 3}$ [transitional conditions - piume rise is affected only by the mean wind and the properties of the phume itsetf (see ref. 32)).

In the above

$$
\begin{aligned}
\Delta_{h} & =\text { plume rise }(\mathrm{m}), \\
x & =\text { distance from stack }(\mathrm{m}), \\
F & =3.8 \times 10^{-5} Q_{h}, \\
Q_{h} & =\text { calones per second of heat output of the stack }=3.6 \times 10^{7},
\end{aligned}
$$




$$
\begin{aligned}
F & =1.4 \times 10^{3} \mathrm{~m}^{4} / \mathrm{sec}^{3}, \\
u & =\text { wind velocity }(\mathrm{m} / \mathrm{sec}) . \\
S & =\text { stability parameter } g / T\left(13^{\circ} \mathrm{C} ; \mathrm{km}\right) \\
& =4 \times 10^{-4} \text { (1! pical stable) } \sec ^{-2} .
\end{aligned}
$$

For neutral conditions with $\bar{u}=10 \mathrm{~m} / \mathrm{sec}$,

$$
\Delta h=(400)(1400)\left(10^{-3}\right)=560 \mathrm{~m} .
$$

A later modet ${ }^{33}$ for neutral conditions sugees s the formula

$$
\Delta h=1.6 F^{-1 / 3} u^{-1}\left(3 x^{*}\right)^{2 / 3}
$$

where

$$
x^{*}=2.16 F^{2 / 5} h_{s}^{3 / 5}=750 \mathrm{~m} \text {. This gives } \Delta h=307 \mathrm{~m} \text {. }
$$

For stable conditions with $u=2 \mathrm{~m} / \mathrm{sec}$,

$$
\Delta h=(2.6)\left(1.8 \times 10^{6}\right)^{1 / 3}=320 \mathrm{~m}
$$

For transitional conditions, assuming $\bar{u}=10 \mathrm{~m} / \mathrm{sec}$,

$$
\Delta h=(2.0)\left(1.4 \times 10^{3}\right)^{1 / 3}\left(10^{-1}\right) x^{2 / 3}=2 x^{2 / 3},
$$

and

$$
H=\Delta h+h_{s},
$$

where $H$ is total height of the plume center line and $h_{s}=$ height of stack above ground, at $x=1000 \mathrm{~m}, \Delta h=$ 200 and $H=337 \mathrm{~m}$. Thus

$$
x_{\max }=\frac{Q}{e \pi \sigma_{y} H \bar{u}}=\frac{Q}{e \pi \sigma_{y} \sigma_{x} u}
$$

and

$$
H=1.40_{2} \text {, }
$$

where $Q$ is tritium source strength $\left(\mathrm{Ci} /\right.$ sec), $X_{\max }$ is maximum tritium concentration $\left(\mathrm{Ci} / \mathrm{m}^{3}\right)$, and $o_{z}$ is vertical dispersion parameter. Using the neutral $\Delta h=307$.

$$
H=307+137=444 \mathrm{~m},
$$

and

$$
\sigma_{2}=\frac{444}{1.4}=316 \mathrm{~m}
$$


For Pasquall's "C" type of turbulence. ${ }^{32-34}$ with sightly unstable wather conditions, $\sigma_{2}=316 \mathrm{~m} \mathrm{at} x$ $=2000 \mathrm{~m}$ and $\sigma_{y}=600 \mathrm{~m}$.

$$
x_{\max }=\frac{6.1 \times 10^{5}}{\cos (316)(600)(10)}=3 \times 10^{-: 2} \mathrm{Ci} / \mathrm{m}^{3}
$$

At his tritivin concentration, anerase aduh will breathe in $3 \times 10^{-12} \times 20=6 \times 10^{-11}$ Co of tritium per dry.

The maximum boty buden of tritiven for continuous exposenre at this leved would be sbout $2 \times 10^{-3}$

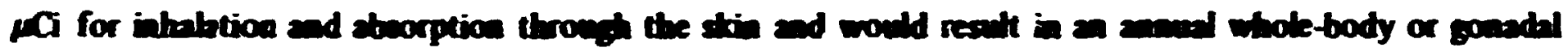

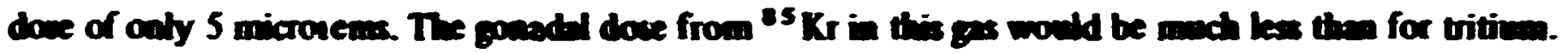

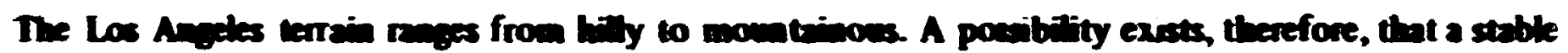

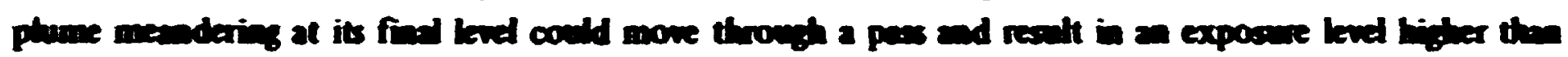

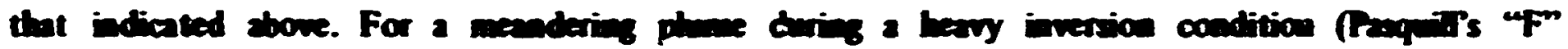
category), ${ }^{32-34} H=400 \mathrm{~m}, \overline{\mathrm{u}}=1 \mathrm{~m} / \mathrm{sec}$ and $X=0 / 200,0_{z}=75 \times 10^{-10} \mathrm{Ci} / \mathrm{m}^{3}$ at $10^{6} \mathrm{~m}$, or $5 \times 10^{-11}$ Ci/m at $10^{5} \mathrm{~m}$.

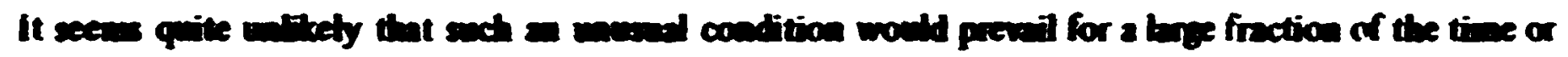

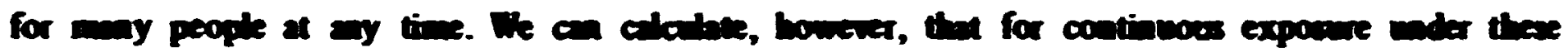

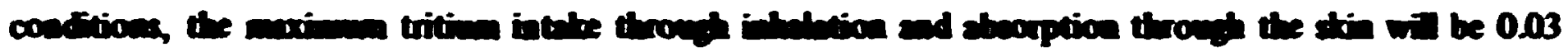

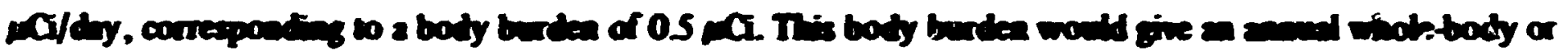

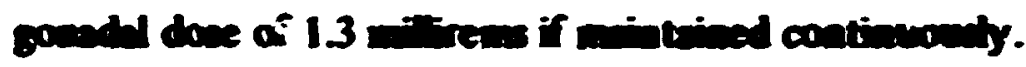

